\title{
Christine M. Korsgaard'da Hayvanlar ve Hayvanlara Yönelik Kimi Pratik Yükümlülüklerimiz
}

\author{
Animals and Our Certain Practical Obligations to Animals in Christine \\ M. Korsgaard \\ BARIȘ MUTLU \\ Van Yüzüncü $\Upsilon_{\imath l}$ University
}

Received: 30.10.2018| Accepted: 06.03.2019

\begin{abstract}
C. M. Korsgaard is a Kantian philosopher, she proceeds in her works with the guidance of Kant, and by this guidance, she argues important subjects as "agent and identity", "self", "normativity", "practical reason", and "animals". In her works she especially argues that normativity has a necessary relationship with human nature, it has a psychological power in human nature as a form of necessity, it functions as the creator of the human soul. Korsgaard believes that: Only the rational person reaches to "the normative principles, laws which will govern the things she/he does and believes", he/she has the skill "to normatively manage himself/herself'. This skill is not available in other non-human animals; they all do not have a capacity of reason, rationality rather they only act with their evolutionary instincts, their natural structures. Korsgaard, however, says that we must not exaggerate this difference and that this difference does not make us morally superior to them. For animals, like us, value their lives, pursuit certain goods and ends, live with certain functions (ergon). In this paper, we will see the Kantian theory which Korsgaard argues about animals.
\end{abstract}

Keywords: Korsgaard, morality, rationality, animals, obligation.

(C) Mutlu, B. (2019). Christine M. Korsgaard'da Hayvanlar ve Hayvanlara Yönelik Kimi Pratik Yükümlülüklerimiz. Beytulhikme An International fournal of Philosophy, 9 (I), I47-I79. 


\section{Giriș}

Felsefe literatürü içerisinde, insanlar ve hayvanlar arasındaki ilișki ve bu ilișkinin etik boyutlarına dair tartıșmalar giderek yer bulmaya bașlamıștır. Hayvanlığımız, hayvanlarla ortaklığımız, hayvanlara yönelik tutumlarımız ve yükümlülüklerimiz Peter Singer, Tom Regan, Jacques Derrida, Alasdair MacIntyre, Christine M. Korsgaard gibi önemli filozoflar tarafindan tartıșılmaktadır. Bu filozoflar arasında ele alacağımız, John Rawls'ın en önemli öğrencilerinden biri olan Korsgaard, hocası Rawls gibi Kantçı bir filozof olarak karșımıza çıkar. Kısa bir süre önce Fellow Creatures: Our Obligations to the Other Animals (2OI8) bașlığıla yayımladığı eserinde, hayvanlara yönelik Kantçı bir okuma girișiminde bulunur. Korsgaard uzun yılların ürünü olan bu eserinde, The Constitution of Agency: Essays on Practical Reason and Moral Psychology (2008), Self-Constitution: Agency, Identity, and Integrity (2009) gibi önceki eserlerinin argümanlarını takip ederek ilerler. Eserlerinde 1srarla vurguladı̆̆ı temel nokta șudur: Hayvan olarak insanların hayvanlar içerisinde en ayırt edici yönleri, rasyonel olmalarına ya da akılsallıklarına bağlı olarak benliklerini/kendiliklerini de kuracak bir șekilde ahlaki "normatif” yasalar inșa edebilmeleridir. Ona göre insanlar, yașamlarını "Kant'ın 'otonomi', normatif olarak kendini-yönetme kapasitesi” ile ahlaki olarak șekillendirebilmekte ve değerlendirebilmektedirler.

Açıkçası Korsgaard'ın bu açıklaması pek de yeni değildir. Çünkü Aristoteles'ten beri felsefe tarihi içerisinde hayvanlar ve insanlar arasındaki benzeri farklılıklar sürekli vurgulanmıștır. Örneğin ilk biyoloji felsefecisi diyebileceğimiz, hayvanlar üzerine eșsiz incelemeleri ve değerlendirmeleri olan Aristoteles'e göre, insanların etik ve politik yașamlarının derinliğini hayvanların yașamlarında göremeyiz. Özellikle doğalarından kaynaklanan anlamlı konușma becerisi ve doğal ihtiyaçları nedeniyle bir araya gelen insanlar, diğer hayvanlara göre çok farklı birlikteliklere hayat verebilmișler, adaleti ve yazılı yasaları tesis edebilmișlerdir. Bu farklılıklara dair tartışmalar hayvanlarla ilișkilerimizi olumlu ve olumsuz etkileyecek bir șekilde bizleri belirlemiștir. Bu tartıșmalarda Korsgaard'ın özgün yönü ise, hayvanlardan yana pek bir șey söylememiș olan Kant'in terimleriyle ilerlemesidir. Kendisi, göreceğimiz gibi, Kant'ın “Amaçlar Krallı̆̆ı” (The Kingdom of Ends) içerisine, yani kișilerin birbirlerini kendilerinde bir amaç olarak ele aldıkları krallığa, hayvanları da dahil etmek ister; salt insanları 
içeren bu "Amaçlar Krallığı"nı hayvanları kapsayacak bir șekilde genișletmeye çalıșır. Bu çalıșmamızda Korsgaard'ın Kantçı bir taslak içerisinde hayvanları nasıl ele aldığı üzerinde duracağız. ${ }^{1}$

\section{I. İnsanlar ve Hayvanlar Arasındaki Farklılıklar}

Korsgaard bir Kantçı olarak eserlerinin neredeyse tümünde, insanların pratik yașamlarını ahlaki normatif yasalarla düzenlediklerine dikkat çekmeye çalıșır. Ona göre insanın bu özelliği, yaratıklar (creatures) ${ }^{2}$ yani tüm hayvanlar içerisinde onun en karakteristik, en ayırt edici yönü durumundadır. İnsanı hayvanlar arasında böylesine farklılaștıran șey ise akılsallık ya da rasyonalitedir (Korsgaard, 2006, s. IO4). ${ }^{3}$ Bu farklılı̆̆ımız ile birlikte elbette hayvanlarla birçok ortaklığımız da mevcuttur. Evrimsel bakıs, açısı, önem vermemiz gereken bir șekilde, bu ortaklıkları gözler önüne sermeye çalıșır (Korsgaard, 20I2, s. 9I-92). Hayvanların yașamlarına baktığımızda onların da bizler gibi fark ettikleri belli amaçlar peșinde koștuklarını görürüz (Korsgaard, 2006, s. IIO-III). Örneğin bir köpek acıktı̆̆ında nasıl davranabileceğini, yemeğe güvenli bir șekilde nasıl ulașabileceğini bilebilir. Bir tehlike gördügünde bekleyip iyice güvenliğinden emin olduktan sonra yemeğe yönelmeyi seçebilir. ${ }^{4}$ Korsgaard hayvanların bu becerileri bașarılı bir șekilde gösterebildiklerini kabul eder. Ancak insanlar, sahip

I Korsgaard'dan önce Regan da Kantçı bir taslak içerisinde hayvanları ele almıștır. İlk baskısı ı983'te yapılan ve henüz Türkçeye çevrilmemiş başyapıtı The Case for Animal Rights (2004)'ta hayvanları ahlaki bir ödevin tartışma konusu kılmaya çalıșir. Ancak Korsgaard'ın Regan'a göre Kantçılığı daha açıktır ve o Kant'ı daha farklı ișler. Örneğin Regan insan ve hayvan arasındaki ortaklıkları Singer gibi güçlü bir biçimde vurgulayarak ilerken, Korsgaard ise farklılıklar üzerinde durarak hayvanlara yönelik bir ödev, yükümlülük alanı açmaya çalışır. Korsgaard'ın bakıș açısı daha insan merkezlidir. Kant'ın ahlaki amaçlar krallığını hayvanlara kadar genișleteceğimizi düșünür. Bu konuda Kant gibi insan aklına güven duyar. Bu tartışmamızda Türkçede henüz bir çalışmanın olmadığı Korsgaard'ın felsefesini ve onun yoğun ilerleyen argümanlarını iyi bir șekilde ele almak ve ortaya koymak istiyoruz. Bu nedenle Korsgaard'n felsefesini, Regan ve Singer gibi teorisyenlerle diyalektik bir tartışma içinde yürütmeyip kendisi ile sınırlı tutacağız.

2 Korsgaard insanların da hayvan olduğunu ama hayvan derken bazen insan olmayan hayvanları anladığımızı, bu nedenle kendisinin hayvanları ve insanları kapsayacak bir șekilde yaratıklar (creatures) kelimesini tercih ettiğini söyler (Korsgaard, 2018, s. 3). Dolayısıyla yaratıklar kelimesinin geçtiği yerlerde kapsayıcı anlamda hayvanları kastetmektedir.

3 Korsgaard insanın akılsallı̆̆ına yönelik bu vurgusu nedeniyle kendisini, açık bir şekilde Aristoteles'e kadar geri giden, insanlar ve hayvanlar arasındaki temel farklara yer vermeye çalışan projeye katkı sağlayan çok eski moda kalmıș bir filozof olarak nitelendirmekten çekinmez (Korsgaard, 2006, s. I04).

4 Burada ele alamadığımız, hayvanların bu gibi belli "kararlar almaları"na, dolayısıyla akılsal hünerlerini gösteren becerilerine yönelik filozofların düșüncelerini değerlendiren tarihsel bir okuma için (bkz. Sorabji, 1993). 
oldukları akılsallığa bağlı olarak eylerken hayvanlara göre çok daha karmaşık bir örüntü içerisinde hareket ederler. Örneğin insanlar amaçlarını çok daha derin bir niyetsellikte (intentionality) seçerler. İnsanlar duyguları, içgüdüleri ve öğrenilmiş istekleri ile hareket eden hayvanlardan farklı olarak - Kant'ın da inandığı bir șekilde - istedikleri amaçlara ulașmanın “iyi bir neden”ini soruștururlar. Belli bir amaç peșinde eylemlerde bulunurken bu eylemlerinin gerekçelerini verecekleri "iyi” ya da "kötü" yarg1lamalarda bulunurlar; eylemlerinin "nedenler"ini bilmek isterler (Korsgaard, 2006, s. IIO-III).

Yani Korsgaard için insanlar, otonomi ve "normatif kendini-yönetme kapasitesi"ne sahip olan akılsallıkları ile, "bir temel (ground) olarak temelin bilincine" uzanan derin bir niyetsellik ve refleksif bir farkındalık içerisinde hareket ederler. Örneğin bu farkındalık ile "bu șekilde hareket etmeli miyim?”, "șu amacım, benim șu belli eylemi yapma eğilimi duymayı istemem, acaba bu eylemi gerçekleștirmek için bana gerçekten bir sebep veriyor mu?" sorularını sorup cevaplar ararlar. Korsgaard adına insanları hayvanlardan farklı kılan tam da bu temel hususlardır, yani reflekslikleri ile "ne yapmalıyım?" șeklinde normatif sorular sormaları ve yașamlarını șekillendirmeleridir (Korsgaard, 2006, s. II3). Yașamımızı, benliğimizi ve kișiliğimizi de inșa edecek bu süreçte (Korsgaard, 2006, s. II6) kendi kendimizi yöneteceğimiz yasaları ve ilkeleri bulur ve böylelikle ahlaki hayvanlar haline geliriz (Korsgaard, 20ı8, s. 45). ${ }^{5}$ Belli ilkelere göre yașamayı öğrenen bu soylu ve ahlaki yönümüzle, "en zorlu koșullarda bile dürüst, cesur ve sorumlu” bir yașam sürmeye çalıșırız (Korsgaard, 2006, s. II7II8). ${ }^{6}$ Ulaștığımız değerlendirici standartlar içerisinde iyi bir insan, iyi

5 Korsgaard insanın akılsallığının en ayırt edici etkinliğinin, bilim ve etik olduğunu düșünür. Ona göre "bilgi ve eylem insan ve hayvan dünyasında ortaktır, ama bilim ve etik bilgi ve eylemin özellikle insani ve akılsal kipleri, bağımsız bir dünya kavramının ifadeleridirler." (Korsgaard, 20I8, s. 52). Korsgaard bu değerlendirmesini yine üzerinde durduğu Joh Stuart Mill ile ilișkilendirir. Çünkü Mill'e göre, bir hayvan olan insan da diğer hayvanlar gibi yeme, içme, cinsellik, fiziksel etkinlik ve duygulanım (affection) hazlarına sahiptir. Ama insanın "șiir, sanat, edebiyat, bilimsel keșif, entelektüel anlama ve ahlaki iyiliği"ni hayvanda göremeyiz. Mill açısından bu hazlar daha üstün hazlardır, dolayısıyla kendisi "tatmin olan bir domuzdansa tatmin olmamıș bir insan olmanın daha iyi olduğunu iddia eder." (Korsgaard, 2018, s. 68-69).

6 Bu bakış açısıyla Korsgaard, duygucu (sensualist) bir çizgide ilerlediğini belirttiği ünlü primatolog Frans de Waal'in açıklamalarına katılmaz. Çünkü de Waal bizlerin de maymunlar (apes) gibi bireysel ilgiler üzerinde salt topluluğun değerleriyle hareket etmemiz gerektiğini öğrenen hayvanlar olduğumuzu düșünür (Korsgaard, 2006, s. II7). 
birer karı-koca, iyi birer ebeveyn, iyi birer öğretmen olmayı isteriz (Korsgaard, 2018, s. 46). ${ }^{7}$

Korsgaard tüm bu sözünü ettiği farklılıklara bağlı olarak birçok beceriler gösteren hayvanların, "akıl” kapasitelerine değil belli bir “zeka”ya (intelligence) sahip olduklarını ve bunları da birbirleriyle karıștırmamız gerektiğini belirtir. Ona göre "zeka dünyaya dair bir öğrenme, deneyime bağlı bir öğrenme, yeni neden ve etki ilișkileri kurma ve bu bilgiyi kendi amaçları peșinde ișler kılma becerisi”dir (Korsgaard, 2006, s. II3). Tüm hayvanlar bu zeka ile dıs, dünyaya yönelerek kimi sorular sorar ve bu sorulara yönelik türlü cevaplar üretirler (Korsgaard, 20I8, s. 40). Bu kapasite ile yapabileceğimiz șey salt kimi sorunlarımızı çözmektir. Öte yandan salt insana özgü akılsallık kapasitesi ise yukarıda da gördüğümüz gibi bu șekilde ișlemez. Bu kapasite bizleri içe yöneltir, zihinsel etkinlikler hakkında ilișkilere odaklanmamıza, eylemlerimizin ve inançlarımızın gerekçelerini sorușturmamıza izin verir (Korsgaard, 2006, s. II3-II4). ${ }^{8}$ Bizler akıl ile "normatif ya da değerlendirici sorular" sorar ve bu sorulara cevaplar ararız. Korsgaard'ın örneği ile söylersek, akıl gücü ile bizler -bir aslandan korkup kaçan ceylandan farklı bir șekilde- korkularımızın nedenleri üzerinde

7 Bununla birlikte Korsgaard'ın dikkat çektiği ve aslında hepimizin tarihsel olarak deneyimlediği gibi, insanı hayvandan ayıran șey soylu ve iyi bir yașam sürme gerçeği kadar kötülüğü ve soysuzluğudur da (Korsgaard, 2006, s. II8). İnsanlar hayvanlar arasında hiçbir hayvanın olamayacağı denli kötü olabilir. Örneğin bir anne ve baba çocuğuna bir köpek kadar bile sevgi ve merhamet göstermeyebilir (Nussbaum, 20I3, s. I4I). Bu kötülükler Korsgaard'ın nitelemesini kullanarak söylersek belki de "insanın hayvani doğasından düșmüș olması"nın (Korsgaard, 2006, s. II8) bir sonucudur. Nietzsche'nin ifadesi ile söylersek "pek fazla insanca" yașamımıza dayanır.

8 Korsgaard'a göre Adam Smith ve onu izleyen Charles Darwin de bu "gerekir"in/"meli"nin/"malı"nın (ought) büyük önemine dikkat çekmiș, normatif olarak kendiniyönetme kapasitesinin ahlaki gelişimdeki belirleyiciliğine önem vermișlerdir. Ancak onlar bu "gerekir"i "sosyal doğamız" ile açıklamaya çalışmışlardır (Korsgaard, 2006, s. II4). Örneğin Darwin için sosyal hayvanlar, zihinsel yetileri geliștikçe, ki "zihindeki bu sosyal içgüdüler sebatkar ve sakindir”, iștahları uğruna-çiftleșmedeki gibi- bu içgüdülere karșı gelen itkilerini kontrol etmeyi bașarırlar (Korsgaard, 2006, s. II5-II6). Yani yapmalısın ya da yapmamalısın șeklindeki normatif açıklamalarımız sosyal bir evrimle gerçekleșir. Smith için ise kişiler, sosyal hayvanlar olarak-sempati aracıllğıyla- diğerlerinin kendilerine dair tepkileri ile içe (inward) yönelerek, kendi motivasyonlarının ve karakterlerinin farkında, bilincinde olmaya bașlarlar. Kișiler bu yolla kendilerinin içsel izleyicileri olduktan sonra, doğal arzularını diğerlerinin övgüsüne ve onayına göre dönüștürmeye başlarlar (Korsgaard, 2006, s. II4-II5). İstekleri de buna bağlı olarak "șunu yapmalıyım" șeklinde bir normatiflik kazanır. Ancak tahmin edeceğimiz gibi Kantçı olan Korsgaard Hume'da da görebileceğimiz bu duygucu (sentimentalist) çizgiyi kabul etmez, failin karakterinin dıșsal bir bakıș açıstyla olușumunu ve kurulușunu benimsemez (Korsgaard, 20I8, s. 2I-22). 
düşünürüz. Bu korkularımıza bağlı olarak eylemlerimizi, tutumlarımızı motive eden olgulara dikkat eder ve bu olgulara yönelik kimi normatif düșüncelere yöneliriz (Korsgaard, 20I8, s. 39-40). Yani Korsgaard için hayvanların salt problem çözmeye yönelik zekası, bizi eylemlerimizin normatif ilkelerine götüren akıldan farklıdır (Korsgaard, 20I8, s. 4I) ${ }^{9}$ ve söz konusu akıl da salt insana özgü bir kapasite olarak karșımıza çıkar.

Korsgaard insanlar ve hayvanlar arasında söz ettiği tüm bu farklılıkları, toparlayıcı nitelikteki șu sözlerle dile getirir:

İlk olarak inançlarımızın, eylemlerimizin temellerinin farkında olmamız, bu temelleri değerlendirebilmemiz ve bu değerlendirmelere göre [belli bir șeye] inanıp edimde bulunmamız anlamında akılsal varlıklarız. İkinci olarak bu eylemlerimize farklı bir karakter veririz; çünkü kendimizi, bize ne yapmamız gerektiğini söyleyen içgüdüler tarafından belirlenen eylemlere sahip olmaktan ziyade, kendi seçtiğimiz ilkelerle yönetiriz. Ne yapmamız gerektiğinin sorumluluğunu alabilecek otonom varlıklarız. Üçüncü olarak eylemlerimizin kaynağı olarak kendimize dair farkındalığımızla birleșik eylemlerimize yönelik değerlendirici ilișkimiz; kendimizle değerlendirici bir ilișkiye, kendi özdeșliğimizin/kimliğimizin (identity) normatif bir kavramına, değerli ya da değersiz, iyi ya da kötü șeyler olarak kendimizle ilgili bir görüșe biçim vermemize yol açar. Bu bizim iyimizin doğasını değiștirir; çünkü bu insanın ya da bizim çoğumuzun iyisi için, kendimizle ve en azından yoldaşlarımızdan bazıları ile iyi bir duruș sergiliyor olmamızda özseldir (Korsgaard, 20ı8, s. 48-49).

9 Korsgaard hayvan ve insan eylemini de bu ayrıma bağlı olarak șöyle ele alır: Hayvanlar doğal ya da evrimsel amaçları (ends) doğrultusunda çime kaçma seçimi gibi bir seçim yaparken, insanlar ise tüm eylemlerine sirayet eden bir seçimle hareket ederler. Örneğin içgüdüler ile bir hayvan aslan gördüğu zaman aslanın dikkatinden kaçmak için (hayvanın doğal ya da evrimci amacı) çime koşma seçiminde bulunur. İnsan ise bir aslan gördüğünde ondan kaçmak için çime koşması gerektiğini bir bütün halinde seçer (Korsgaard, 20I8, s. 42-42). Hayvanlar zeka sahibi olarak yaptıkları șeyleri bilseler ve amaçlarını hangi koșullarda nasıl kovalayacakları konusunda iyi tepkiler verseler bile söz konusu amaca içgüdüsel olarak sahiptirler. Akıl sahibi insanlar ise eyleminin amacını maksimlerle, ilkelerle değerlendirirler, böylece peşinde koșacakları amaçları seçerler. Bu seçimi de hayvanlar gibi içgüdüleriyle değil otonom olmalarıyla, kendi koydukları yasalar ile gerçekleștirebilirler. Böylece Korsgaard'ın daha önce de vurguladığı gibi, "inançlarının ve eylemlerinin temellerinin farkında” bir șekilde hareket ederler (Korsgaard, 20I8, s. II9-I2O). Kısaca insan söz konusu olduğunda, seçim tüm eylemi kapsar. Korsgaard bu ayrımla evrimci bakıș açısına gelmeyen bir yönümüzün olduğunu vurgulamaya çalıșır. Oysa ölümden korkmak, diğgerlerinden onay görmek gibi hayvanlarla evrimsel kökenlerimize, ortaklıklarımıza yeterince dikkat etmez. Zeka ve akıl arasındaki ilișkiyi, kendi amaçları doğrultusunda fazlasıyla keskin bir biçimde ayırır. 
Bu alıntıda dikkat etmemiz gereken kilit nokta, eylemlerimize yönelik değerlendirici ilișkilerin kendimize yönelmeleri, kendimizle ilgili görüșlere biçim vermeleri, hayvanlar da dahil bașkalarıyla olan ilișkimizi belirleyecek olmalarıdır. Açıkçası Korsgaard bu bakış açısının, diğer insanlar kadar hayvanlara karșı da "iyi” bir șekilde duruș sergilememiz için bir umut olacağını düșünür. Bu umudun zorlu tarafı ise Kant'ın hayvanlar konusunda pek bir șey söylememiș olmasıdır. Kant, Aristoteles’in hayvanlara gösterdiği ilgiden çok uzaktır; Aristoteles gibi hayvanlara yönelik bir çalıșması da mevcut değildir. Ancak Korsgaard tüm bu gerçeğe rağmen hayvanlara Kantçı bir perspektifle bakabileceğimizi, hayvanları ve hayvanların sorunlarını Kantçı terimlerle yine de ele alabileceğimizi düșünür. Kantçı terimlerle, Kantçı felsefe taslağı içerisinde hayvanlara karșı (insanlara karşı olduğu gibi olmasa bile) önemli yükümlülüklerimiz olduğunu göstermek ister (Korsgaard, 20ı8, Önsöz, s. XI.). İnsanlar ve hayvanlar arasında üzerinde durduğumuz tüm farklılıklara rağmen onları kendinde bir amaç, kendinde değerli olarak ele alabileceğimiz Kantçı bir yükümlülük alanı bulmaya çalışır. Açıkçası insanlara bu konuda güven duyar; çünkü belirttiği gibi, insanlar hayvanlara- de Waal'in vurguladığı bir șekilde- "salt ayakta duran nesneler" gözüyle bakmalarının hatalı olduğunu bilen tek türdür (Korsgaard, 2006, s. II8-II9). Korsgaard tam da bu hatayı göstermeyi ister, hayvanları salt bir araç olarak değil kendilerinde bir amaç olarak ele almamız gereken nedenleri açık kılmaya çalıșır. Artık Korsgaard'ın söz konusu girișimini ele almaya bașlayabiliriz.

\section{Hayvanlar ve Amaçlar Krallığı}

Korsgaard söz ettiği farklılıklarımıza bağlı olarak insanların kendilerini ahlaki bakımdan daha "üstün” gördüklerine dikkat çeker. Vurguladığı gibi reel yașamın her alanında hayvanların yașamlarını kendi ahlaki yașamlarımız kadar önemli ve değerli görmeyiz. Biz insanlar için öncelikli olan kendi yașamımız ve bu yașamın devamlılı̆̆ıdır. Kendi sorunlarımız karș1sında hayvanların sorunlarını sorun olarak bile nitelendirmeyiz. Hatta hayvanları kendi amaçlarımız için acımasızca bir araç olarak kullanmaktan kaçınmayız (Korsgaard, 20ı8, s. 6-7, 9). Örneğin "bu yoldaș yaratıkları" salt yemek için fabrika çiftliklerinde yetiștirebiliyoruz. Ayrıca onları köpek dövüşleri, avlanma, at yarıșları gibi gaddarca eğlencelerin parçası kılabiliyor, "çeșitli spor ve eğlence etkinlikleri için kontrol edebiliyor ya da 
öldürebiliyor”, “onlar üzerine deneyler yapabiliyor”, ayrıca "nerede yașayacaklarına karar verebiliyor", "onlardan ürünler yapmak” için rahatça faydalanabiliyor ve "projelerimize engel olduklarında ise onları öldürebiliyoruz." (Korsgaard, 20I8, s. 4, 6). Gerçekten de hayvanların, hatta doğa dahil tüm canlıların yașamlarına karșı yıkıcılı̆̆ımız eși benzeri görülmeyecek bir büyüklüktedir. Doğanın, talihin tarih içerisinde yıkıcılığı, özellikle kapitalizmle birlikte insanın gerçekleștirdiği yıkıcılık karșısında pek önemsiz durmaktadır.

Korsgaard tüm bu acımasız reel durumlar içerisinde, hayvanlara yönelik eylemlerimiz ve yașam tarzımız üzerinde ahlaki olarak ciddiyetle düşünmemiz gerektiğini belirtir. Çünkü șu an için hayvanlarla kurduğumuz ilișki, birçok sıra dıșı ahlaki kararlarımızdan farklı olarak yașamlarımızın merkezinde yer almaktadır (Korsgaard, 20I8, s. 4-5). Bu ilișki onları yemek için yetiștirip öldürmek gibi kimi durumlarda fazlasıyla sıradanlașmıștır. Kimi durumlarda ise hayvanları eğlencelerimiz için suiistimal etmek ve öldürmek, iș göremeyecek yașa geldiklerinde terk etmek, kendi yașam alanlarımız içerisinde istememek gibi yine acımasız ve daha bilinçli bir biçimde gerçekleșebilmektedir. Öte yandan hayvanlarla ilișkimizi, evlerimizde onların bizler için birer yoldaș olabilecekleri bir düzeyde kurabilmekteyiz. İște evde kedileriyle yașayan ve bir vejetaryen olan Korsgaard (Korsgaard, 2oI8, Önsöz, s. XI), böyle bir durum içerisinde hayvanların sorunlarının temel nedeninin biz insanlar olduğuna dikkat çeker. Bu nedenle hayvanlara yönelik seçimlerimizin, kararlarımızın ve ilișkilerimizin ahlaki boyutları üzerine farkındalık yaratacak bir tartıșma yürütmeye çalıșır. Özellikle insanların sebep oldukları sorunlar karșısında, "hayvanların tam olarak insanlar kadar önemli ve değerli olduklarını” görmemizi ister (Korsgaard, 20ı8, s. 6). Çünkü kendisinin haklı olarak belirttiği gibi, bu dünyayı hayvanlarla ortak paylașıyoruz ve onların da bir șekilde duyarlılıkları (sentinents), zekaları ve kendi-farkındalıkları vardır (Korsgaard, 20ı8, s. 4). Hayvanlar da bir benliğe/kendiliğe, kișisel bir özdeșliğe/kimliğe, bir kendilik-bilincine sahiptirler ve belli iyileri ve kötüleri vardır (Korsgaard, 20I8, s. 30-33). Örneğin bir kendilik-bilinci formu olarak tartıș1labilecek haz ve acıları ile kendilerini dünyadan ayırır, kendilerini ve kendi koșullarını değerlendirir ve bu koșulların farkına varırlar (Korsgaard, 2OI8, s. 3I). 
Korsgaard için bu kendilik-bilinci formu ayna testini geçemeyen ${ }^{\mathrm{IO}}$ hayvanlarda bile vardır; çünkü ilișkisellikte de bir kendilik-bilinci bulunur. Mesela bir kaplan avı için çömeldiği zaman, avının ve kendi pozisyonunun, fiziksel yerinin farkında olarak hareket eder (Korsgaard, 20I8, s. 3I). ${ }^{\text {II }}$

Burada Korsgaard'ın ve hatta birçok düşünürün dikkat çektiği gibi, hayvanların kendi yaşamlarına ne denli değer yükleyebileceklerini kimi ortaklıklarımıza dikkatle fark edebiliriz. Örneğin hayvanlara yönelik araștırmalarda çok merkezi bir rol oynayan Darwin -The Descent of Man bașliklı eserinde- dil ve alet kullanımının kökenlerini, estetik duyarlılık ve diğer insani kapasiteleri hayvanlarda bile görebildiğimizi belirtir (Korsgaard, 20ı8, s. 55). Günümüzde çalıșmaları ile çok ses getirmiş olan de Waal ise yine hayvanlar ile insanlar arasında ne denli güçlü kökensel ortaklıkların olduğunu empirik araștırmalar ile bize göstermeye çalıșır. De Waal, MacIntyre'a dikkatle, hayvanların da bizler gibi ahlaki bir dünyaları olduğunu benimseyecek bir șekilde, ahlakın; "hayatta kalmak için bir destek sistemine dayandırdığımız bir olgudan doğan grup-yönelimli bir fenomen" olduğunu (de Waal, 2006, s. I6I), "karș1lıklı bir bağımlılık olmadan diğerleriyle yașayan bir insan" olunamayacağını ve "yalnız (solidarity) bir insanın da ahlaka ihtiyaç duymayacağını" söyler (de Waal, 2006, s. I62). Ona göre ahlak tam da böyle bir gerçeklik temelinde, kendi aile ve klanımızdan

Io Ayna testi hayvanın kendini fark etme, tanıma becerisini gösterip gösteremeyeceğini ortaya çıkartmaya çalışır. Test için "hayvanın bedenine kırmızı bir boya sürülür ve hayvan aynanın önüne bırakılır”. Șayet hayvan bu boyalı kısmı fark eder ve aynadan uzaklașarak bedenindeki bu bölgeye yönelip onu çıkarmaya çalışırsa, yani bedenindeki șeyi merak ederse "aynada kendini fark ettiği", belli bir bedenin kendi bedeni olduğunu bildiği, aynadaki hayvanın kendisi olduğunu fark ettiği kabul edilir. Maymunlar, filler ve kimi kușlar bir șekilde bu testi bașarıyla geçmișlerdir. Ancak Korsgaard yukarıda belirttiğimiz gibi, bu testi geçemeyen hayvanların kendilik-bilincinden yoksun olduklarını düșünmez (Korsgaard, 20I8, s. 31).

${ }^{\text {II }}$ Korsgaard bu benlik vurgusuyla, Kant'n benliği/kendiliği "zamanla birleșik duran bir bilinç türüne sahip olmakla ilișkilendirmesini” așırı bir görüș olarak kabul eder (Korsgaard, 2018, s. 32). Korsgaard'a göre Kant'ın diğer bir așırı görüșü de Saf Aklın Kritiği’nde 'Ben' idesinin önemini, "Bence”nin (I think) tüm düșüncelerimize bağlanmak zorunda olduğu olgusuna dayandırması"dır (Korsgaard, 20I8, s. 34). Korsgaard'ın Kant'ın bu açıklamalarına karșı iki itirazı vardır. Birinci itirazı hayvanların bir benliğe sahip olup benliğin aslında salt bir derece sorunu olarak karșımıza çıkmasıdır. Çünkü hayvanlar da zaman içerisinde ișlevsel belli bir bakıș açısını, zamanla belli bir kișisel devamlılığı edinebilir, öğrenebilirler; beğenileri vardır, dostlar edinirler, projeleri ve rolleri bulunur (Korsgaard, 20r8, s. 32). İkinci olarak Kant'in, her ne kadar ifade etmemiș olsa da, "bence"si "bir bütün olarak tutarlı kavramına" ulașmayı amaçlayan bir ișlevsel birlik olarak görülebilir. "Bence"yi dünyada kendi yolumuzu bulacağımız bir ișlevsel birliğin ișareti olarak ele alabiliriz (Korsgaard, 2018, s. 34). 
komünitemize/topluluğumuza oradan millete, insanlı̆̆a ve tüm yașam normlarına doğru gelișir (de Waal, 2006, s.I63-I64). İnsan adım adım etkin k1labileceği bu ahlaki kapasiteler içerisinde belli temel düzeyleri, "empati”yi, "karș1lıklılığı" (reciprocity), "hak edilen cezayı" (retribution), “çatıșmaların çözümünü”, bir "hakkaniyet duygusu"nu (a sense of fairness) diğer primatlarla paylașmaktadır (de Waal, 2006, s. I66-I67). ${ }^{\mathrm{I2}}$

Hayvanlarla bu paylașımlarımızdan, ortaklıklarımızdan biri de MacIntyre gibi filozofların dikkat çektiği gibi "bağımlılıklarımız"dır. Özellikle bebeklik ve yașll1ık dönemlerine, engellilik durumlarına baktığımızda hayvani yönlerimizin bizler üzerindeki etkili olan bağlayıcılıklarını ve asında yaşamlarımızı nasıl etkilediklerini yașam boyu fark etme imkanımız olur. ${ }^{13}$ Isște hayvanlarla ortaklıklarımıza dikkat eden tüm bu açıklamaları düşündügümüzde de Waal'den etkilenen Martha C. Nussbaum'un insan olmayan hayvanlara yönelik șunu vurgulaması anlamlı ve önemlidir: İnsan olmayan hayvanlar tüm farklılıklarımıza rağmen, görmezden gelemeyeceğimiz kimi sahip olduğumuz ortaklıklara bağlı olarak, adalet tartıșmasının bir parçası olmalıdırlar (Nussbaum, 2007, s. 325-326-v.d.). Çünkü onlar da bizler gibi yemek, içmek, cinsel etkinliklerde bulunmak, bebekleriyle oynamak, sıcak ve rahat bir ortamda yașamak ve yoldașlara sahip olmak isterler (Korsgaard, 20I8, s. 22). ${ }^{14}$ Kisaca iyi ve kötü görece-

${ }^{12}$ De Waal insanların ve maymunların karșılaștırmaları üzerinden ahlakın üç aşamasını șu șekilde ortaya koyar:

I. "Ahlaki duyarllıklar" (moral sentinents) düzeyi: Bu düzeyde insanlar ahlakın temelleri olarak "empati kapasitesini”, "karșılıklılık eğilimi”ni, "bir adalet duygusu”nu, "ilișkileri uyumlu kılma becerisi”ni gösterirler ve bu düzey diğer primatlarda da mevcuttur.

2. Sosyal baskı (social pressure) düzeyi: Bu düzeyde insanlar "iș birliğine dayanan grup yașa$\mathrm{m}$ lehinde davranıșlar sergilerler." Bu "topluluk ilgisi ve buyurgan sosyal kurallar diğer primatlarda da vardır, sadece bir bütün olarak toplum amaçlarına yönelik ilgi ve sosyal baskı daha az sistematik, daha az ilgi çekicidir."

3. "Yargılama ve akıl yürütme" (judgement and reasoning) düzeyi: Bu düzeyde "diğerlerinin ilgileri ve amaçları bizim davranıșları yargılamamızı- doğrudan bize dokunmayanların davranışları da dahil- șekillendirdiği ölçüde diğerlerinin ihtiyaçlarını ve amaçlarını içselleștirme mevcuttur. [Bu düzeyde] ahlaki yargılama öz-refleksiftir (yani kendi davranıșlarımızı da yönlendirir) ve sıklıkla mantıksal olarak bir sebebe dayanır. İște "diğerlerinin ihtiyaçları ve amaçları her iki grup için belli düzeyde içselleșebilse de [bu düzey] benzerliklerin son bulduğu yerdir." (de Waal, 2006, s. I68).

${ }^{\text {I3 }}$ Bağımlılığı, hayvanlar ve hayvanlığımız üzerinden ele alan etkileyici bir okuma için (bkz. MacIntyre, 2002).

${ }^{14} \mathrm{Bu}$ dostluk ilișkisinin hayvanlardaki merkezi rolünü, hayvanlar üzerine eșsiz çalıșmaları ve değerlendirmeleri olan Aristoteles'in vurgulaması anlamlıdır. Korsgaard'n dikkat çektiği ve son dönemlerde vizyona giren Alfa Kurt (Alpha) (2018) filminde göreceğimiz gibi; örneğin köpeklerin dostluğa, topluluğa duydukları ihtiyaç ve gereksinim insanlarınkinden fark- 
ğimiz bu isteklere tüm yaratıklar, yani insan kadar insan olmayan hayvanlar da sahiptirler. Nussbaum'un ifadeleriyle söylersek, bu ilișkiler bak1mından onlar da adalet tartıșmasının bir konusudurlar (Nussbaum, 2007, s. 326) ve kapasitelerine, ișlevlerine saygı ve özen göstermemiz gereken canlılardırlar. Çünkü insan olmayan hayvanlar da bizler gibi ișlevlerini yerine getirecekleri belli kapasitelerle doğarlar ve bu kapasitelerini etkin kılmada "maddi ve sosyal çevrenin desteğine ihtiyaç duyarlar" (Nussbaum, 20I2, S. 229). ${ }^{15}$

İmdi Korsgaard da bu filozoflar ve düșünürler gibi hayvanların bizlerle ortaklıklarına, onların yașamlarına yükledikleri değerleri ve iyileri gözeterek, onları ve yașamlarını değersiz görmememiz gerektiğini belirtir (Korsgaard, 20I8, s. I5-ı6). Çünkü tüm yaratıklar yani insanlar kadar hayvanlar da bizzat belli değerlerle yașarlar; belli ișlevlerle [ergon] hareket ettiklerinden dünyayı değerlendirici bir gözle görürler; șeylere çekici ve peșinde koșulacak ya da caydırıcı ve uzak durulacak bir șekilde yönelirler. Kendi koșullarını, bu koșulları etkileyecek șeyleri iyi ve kötü olarak ele alırlar (Korsgaard, 20I8, s. 20-2I). Korsgaard bu önemli ortaklıklarımıza, yani hayvanların da bizler gibi yașamlarına değer yüklediklerine dikkat ederek, yerinde bir șekilde șunu vurgular: "Bizlerin ahlaki doğası, ahlaki standartları hayvan eylemine uygulamamamıdan dolayı bizleri daha iyi kılmaz." (Korsgaard, 20I8, s. 53). Hayvanlardan daha zeki olmamız, daha üstün entelektüel beceriler ortaya koymamı, bizlerin "daha yüksek bir ahlaki mevki”de yer aldığını göstermez (Korsgaard, 20I8, s. 60). ${ }^{16}$

Korsgaard Aristoteles'in ișlev kavramından hareket eden bu açıkla-

1 değildir. Hayvanlarla dostluk ilișkisini Aristotelesçi Aquinalı Thomas'ın düșündügü gibi olanaksız olarak nitelendirmek (Coetzee, I999, s. 65) doğru olmayacaktır. Belki de hayvanlarla dostluğumuzu, Aristoteles'in dostluk tartıșmasında aynı seviyede olmayacak olsa da erdemli kișilerle kurduğumuz dostluğun içerisinde bir yere koyabiliriz. Çünkü bu dostluk da temel olarak karşılıksız, kendinde bir amaç olan iyiler üzerinde yükselir.

${ }_{15}$ Ancak Nussbaum için kendi kapasiteler yaklașımının merkezinde insanın saygınlığı vardır (Nussbaum, 2007, s. 346).

${ }^{16}$ Korsgaard bu açıklamalarını, yaratıkları bir önem hiyerarșisinden uzak tutma çabası olarak görmemizi ister. Ona göre amacı Singer gibi insanlar ve hayvanları eșit önemde ele almak değildir. Tartıșmasında asıl odaklandığı nokta, yaratıkların "kendileri için șeylerin önemli olduğu varlıklar” olduklarıdır (Korsgaard, 20I8, s. 63). Örneğin ölüm, Jeff McMahan'in ișaret ettiği gibi, kompleks bir narratif/anlatısal yapıya sahip olan insan için, böyle bir yapıya sahip olmayan hayvana göre daha kötü yani daha değerlidir (Korsgaard, 20I8, s. 66). Ama Korsgaard için bu değerlilik bahsettiği tarzda bir hiyerarșiye yol açmamalıdır. Tavșanın ölümle ilișkisini kendi bakıș açımızla görmememiz gerekir (Korsgaard, 2OI8, s. 65-66). 
malarını, hayvanları kendinde amaç olarak ele alacağımız bir Kantçı okumayla birleștirmek ister. Kendisi, Nussbaum'un da dikkat çektiği gibi, hayvanlar konusunda işlev tarzında Aristotelesçi bileșenlerle birlikte Kantçı bir yaklașım geliștirmeye çalıșır (Nussbaum, 20I2, s. 230). ${ }^{17}$ Gelgelelim Korsgaard bu sentez yolunda șöyle bir zorlukla karșılașır: Kant'in kendisi hayvanlara karşı yükümlülük içerisinde olacağımız bir değerlendirmeyi ahlak teorisinin açık ve güçlü bir parçası kılmaz (Nussbaum, 2007, s. 329). Çünkü Kant- Roma yasasını takip ederek- Groundwork'te ahlaki dünyayı "kișiler" (persons) ve "șeyler" (things) olarak ikili bir ayrımla ele alır ve insanın karșısına insan olmayan hayvanlar da dahil olmak üzere her șeyi koyarak ilerler (Korsgaard, 2013, s. 629-63I). Böyle bir ayrıma yol açan șey ise insanların rasyonalitelerine ya da akılsallıklarına bağlı olarak bir "Amaçlar Krallı̆̆ı” nı kuracak șekilde seçimleri ile kendi yasalarını yapmalarıdır. Bu krallıkta akılsal her insan "kendinde bir amaç olarak" "içsel bir değer"e, "haysiyet"e (dignity) sahiptir ve satın alınacak hiçbir ücreti/fiyatı yoktur. Bunun karșısında yer alan șeyler ise insanlardan farklı olarak böyle bir kendinde değer tașımayıp belli bir ücretle satın alınabilirler, bir araç olarak göreceli bir değerdedirler. İște hayvanlar da akıldan yoksun olmaları nedeniyle bu șeyler grubu içerisinde yer alırlar, yani araçsal bir değer taşırlar (Korsgaard, 2013, s. 631; Kant, 2002, s. 52). ${ }^{18}$ Hayvan-

${ }^{17}$ Nussbaum, Korsgaard'ın Aristotelesçi bileșenlerle ilerleyen Kantçllı̆̆ının "hayvanların etik ele alınması için uygun bir temel teklif edebileceğine" inanır (Nussbaum, 20I2, s. 230). Ama burada ele alamayacağımız Kantçı bileșenleri içeren Yeni-Aristotelesçi (NeoAristotelian) (Nussbaum, 2012, s. 230) kapasiteler yaklașımı temelinde ilerler. Frontiers of fustice'daki ifadesiyle söylersek, kapasiteler yaklaşımının daha iyi bir teorik rehber olabileceğine inanır görünür (Nussbaum, 2007, s. 327). Çünkü Nussbaum Rawls gibi politik bir yaklaşım içerisinde hareket ederek, "makul insanlar" nn paylașacakları insan olmayan hayvanlara yönelik ortak bir zemin bulmaya çalıșır. Bu nedenle Korsgaard'ın insanın "insanların dünyadaki değerin tek kaynağı" olacağı açıklamasının kimi makul insanlar için ortak bir zemin veremeyeceğini düșünür (Nussbaum, 20I2, s. 230-23I). Dolayısıyla Nussbaum, son dönem eserlerinde görebileceğimiz gibi, Korsgaard'ın kapsamlı bir etik teori geliștirme ilgisi yerine politik olana dikkatle ilerler. Nussbaum'un kapasiteler yaklașımıyla ilgili (bkz. Erkızan, 20I2; Mutlu, 20I5).

${ }^{18}$ Korsgaard Kant'ın hayvanlarla ilgili söz konusu açıklamaları içerisinde özellikle Kant'ın şu pasajlarına dikkatimizi çeker:

"Varolușu istencimize (will) değil doğaya dayanan varlıklar, eğer akıldan yoksun varlıklarsa, sadece göreceli, araç olarak bir değere sahiptirler ve bu nedenle șeyler olarak adlandırılırlar, öte yandan akılsal varlıklar ise, doğaları onları hali hazırda kendilerinde bir amaç olarak belirlediği için kișiler olarak, yani salt bir araç olarak kullanılamayacak șeyler olarak adlandırilırlar." (Groundwork, 4:428) (akt. Korsgaard, 2018, s. 98, II4 ve I. dipnot).

"[insan] koyuna ilk kez 'giydiğin post sana doğa tarafından kendi kullanımın için değil benim için verildi' deyip, postu giymek için koyundan aldığında tüm hayvanların üstünde 
ların da içinde yer aldığı bu șeylere yönelik hiçbir ahlaki ödevimiz yoktur; yani ahlaki ödevler "kendilik-bilincine sahip olmayan hayvanlar"a değil salt "kendilik-bilincine sahip varliklar olan insanlar"a yöneliktir (Nussbaum, 2007, s. 329). Kısaca Kant insanların amaçlarının nesnel temelini, onların sahip olduğu akıl ve akılsal istemeyle ilișkilendirir (Kant, 2002, s. 45), insanın eylemlerinin kendilerinde amaç olmasını salt akılsallık temellinde ele alır (Kant, 2002, s. 47). Onun için belli bir yasal birlik olan "Amaçlar Krallığı" "çeşitli akıl sahibi varlıkların, ortak yasalar aracılı̆̆ıyla kurulan sistematik birliği”dir (Kant, 2002, s. 5I).

İmdi Kant'in bu açıklamalarına bağlı olarak ahlak teorisini salt akılsal varlıklarla sınırlandırdığı çok açıktır (Korsgaard, 20I8, s. 55). Çünkü Kant için sadece akı1sal ve otonomi sahibi insanlar diğer akılsal insanlarla karș1lıklılığa (reciprocity) dayanan, birbirlerine karșı yükümlülükler, ödevler taşıyan bir ilișki içerisinde olabilirler. Ahlaki topluluğu olușturan ve sınırlarını belirleyen böyle bir karșılıklı ilișkiyi de akılsal ve otonom olmayan hayvanlarla kuramayız; dolayısıyla onlarla bu ahlaki topluluğun içerisinde bir ilișki tesis edemeyiz (Korsgaard, 20I8, s. 96). Bu toplumun, yani birbirimize belli yükümlülükler ve ödevler yüklediğimiz ve karșlıklı bir yasa içerisinde hareket ettiğimiz "Amaçlar Krallı̆̆ı"nın bir parçası olmadıkları için de (Korsgaard, 20I8, s. I25) hayvanlara karșı bir adalet ödevi gibi bir ödevi borçlu değiliz. Bir anlaşmanın, sözleșmenin parçası olamayacak hayvanları adalet ödevinin bir parçası kılamayız (Korsgaard, 20I8, s. II6). ${ }^{19}$

keyif almıș olduğu... bir ayrıcalığın farkına vardı ve onları artık yoldaș yaratıklar olarak değil keyif aldığı herhangi bir amacı elde etme isteği için kullanılan araçlar ve vasıtalar olarak kabul etti. Bu nosyon șu ayrımın farkındalığını ima eder: İnsan diğer insanlara, hayvanlara yöneldiği gibi yönelmemelidir ama onları doğanın hediyeleri içerisinde eșit bir paya sahip olarak kabul etmelidir... O halde insan kendinde amaç olduğunu iddia edebildiği için...tüm akılsal varlıklarla eșit bir seviyeye ulașmıștı...” "“Conjectures on the Beginning of Human History" 8: II4) (akt. Korsgaard, 20I8, s. 98 ve 4. dipnot).

"Hayvanlara eziyet edeceğimiz, onların sstırap çekmelerine izin vereceğimiz ya da onlara sevgisiz bir șekilde davranacağımız herhangi bir eylem kendimizi alçaltır." (Lectures on Etbics, 27: 710). (akt. Korsgaard, 2018, s. 98). Kant'ın bu pasajlarına dikkatle Korsgaard'ın belirttiği üzere; Kant kendimiz ve karşılıklı ilișki içerisinde olduğumuz diğer insanları bir amaç olarak ele alırken, hayvanları bir araç olarak ele alacağımızı düșünür. Ancak Korsgaard'a göre Kant bu araçsallığı, kesinlikle hayvanlara kötü davranmamız anlamında kullanmaz (Korsgaard, 2018, s. 99-100).

19 $\mathrm{Bu}$ anlayıș sözleșmeci filozoflarda, hatta Batı kültürü kadar birçok kültürün merkezinde bulunur. Sorabji'nin dikkat çektiği gibi, hayvanların adaletin konusu olmaması Hesiodos gibi ozanlarda, Aristoteles ve günümüzde Rawls gibi filozoflarda da mevcuttur. Örneğin Hesiodos'a göre "Zeus adaleti hayvanlara değil, salt insanlara vermiștir." (Sorabji, I993, s. II7). Rawls ise "bir adalet duygusundan yoksun olan hayvanları" adalet tartıșmasının konu- 
Pekala “Amaçlar Krallı̆̆ı” içerisinde biz insanların "Amaçlar Krallığı”nın dıșında yer alan hayvanlarla ilișkisi nasıl olacaktır? Kant bu ilișkiyi paylaștı̆̆ımız özelliklere bağlı olarak salt "benzerlik" (analogy) üzerinden yürüteceğimizi düșünür (Korsgaard, 20I8, s. 96). Bu benzerlikle Kant'ın demeye çalıștı̆̆ı șey; hayvanlara saygılı davranmamızın, böyle bir ödevi tașımamızın ve bu ödevi büyütmemizin bir șekilde insanlarla ahlaki ilișkimize de katkı sağlayacağı, ahlaki doğal eğilimlerimizi de güçlendirecek olmasıdır. Diğer bir deyișle, Kant hayvanlara yönelik ödevlerimizin insanlığa karșı ödevleri etkileyeceğini, bu pratiği ekip büyütmenin insanlığa karșı ödevleri de ekip büyütmeye katkı sağlayacağını düșünür (Korsgaard, 20I8, s. IOI; Nussbaum, 2007, s. 329-330). Onun için insanların "hayvanlara iyi davranma ödevini borçlu olması doğrudan hayvanlara yönelik olmaktan ziyade kendimizle ilgilidir ve bu ödevin temeli de hayvanları kendi karakterimize bağlı ele aldı̆̆ımız tarzı etkilemesine ya da "ahlaka hizmet edebilen” duygularımızı etkilemesine dayanır.” (Korsgaard, 20I8, s. IOI). Yani Kant için insanların hayvanlara yönelik doğrudan değil salt "dolaylı bir ödev"i vardır (Korsgaard, 20I8, s. IOI). Bir bakıma hayvanlar merkezde yer alan "Amaçlar Krallı̆̆ı"na dolaylı bir katkı sağladıkları için değerlidirler.

Gelgelelim Korsgaard, Kant'ın hayvanlarla ilgili bu açıklamalarında kendi kavramlarının imalarını tam olarak takip etmediğini, tam olarak anlamadığını düșünür. Korsgaard için Kant'n "Amaçlar Krallı̆̆ı” ya da ahlaki topluluğu sadece akılsallığa sahip oldukları için yasalar yapan üyeler olarak insanlarla ilișkilendirmesi ve bu topluluk içerisinde hayvanlara yer vermemesi bir hatadır. Çünkü Korsgaard'ın haklı olarak vurguladığı gibi,

su yapmaz (Sorabji, I993, s. II9). Hayvanlara "acı çektirmenin yanlıș olduğunu” düșünse bile, adaleti merkeze aldığı "sözleșme doktrini”ni hayvanları içine alacak șekilde genișletmez (Nussbaum, 2007, s. 33I). Sorabji'nin vurguladığı üzere kimileri adaleti, politik hakları salt akı1sal, bilinçli varlıklarla ilișkili ele alabilir (Sorabji, I993, s. II6). Hatta kimileri hayvanları yiyecek ve tıbbi araștırmalar için öldürmeyi acı verici bulsa da yine de bir adaletsizlik olarak değerlendirmeyebilir (Sorabji, I993, s. II8). Sorabji belki de haklı bir șekilde hayvanlara karșı bugün nasıl bir tutum içerisinde olacağımıza yönelik etik ve politik krizin Aristoteles ile başladığını düşünür. Çünkü ona göre Aristoteles "aklı" (logos/reason) (DA 3.3. 428a24; $E E$ 2.8, 1224a27; Pol. 7.13, 1332b5; NE 1.7, го98a3-4), "akıl yürütme"yi (logismos/reasoning) (DA 3.IO, 433ar2), “düșünce"yi (dianoia/thougt), “intellekt"il"anlak" (nous/intellect) ve "inanç"1 (doxa/belief) salt insana özgü görmesi ve hayvanların bunlardan yoksun olduklarını kabul etmesi neticesinde, özellikle zihin felsefesi ve ahlak felsefesi içerisinde önemli bir krize yol açmıștır (Sorabji, I993, s. 7, I2-I4). Bu krizlerden biri, belirttiği gibi, insanların kendilerini hayvanların üstüne yerleștirmeleri neticesinde hayvanlara karșı nasıl bir ahlaki sorumluluk içerisinde olacakları konusudur (Sorabji, 1993: s. 7). 
bizler sadece akılsal varlıklar değil belli bir iyiye sahip hayvanlarızdır da. Dolayısıla kendinde amaç olmamız ile akılsal varlıkların kendinde amaç olması eș değildir. Korsgaard bu hassasiyeti gösterme konusunda Kant'ın yeterince dikkat etmediğini ve aslında Kant'ın kendi teorisinde bile sözünü ettiği ayrımların karar verici olamayacağını belirtir. Korsgaard'a göre akılsal varlıklar olarak bizler, yine Kantçı bir taslak içerisinde ahlak yasalarını diğer hayvanları koruyacak ve onları kendinde amaç olarak ele alacak bir șekilde genișletebiliriz (Korsgaard, 20I8, s. I3I-I32). Hatta bunu yapabildiğimiz takdirde, yani onların değerini bir amaç olarak ele alabildiğimiz bir durumda, kendimize de hak ettiğimiz değeri gerçek anlamda verebiliriz (Korsgaard, 20ı8, s. II3), kendimize akılsallığımızın ve bedenselliğimizin birliği içerisinde de bir amaç olarak bakabiliriz.

Korsgaard bu kapsayıcılık talebi ile Kant'ın felsefesine yönelik kilit önemde gördüğü șu konuya dikkatimizi çeker:

Aslında Kant'ın argümanında işler halde ve hafifçe farklı olan aktif ve pasif anlamlar șeklinde düşünebileceğimiz anlamlar vardır. Eğer seni benim için yasa yapma becerisinde kabul edersem ve beni, hem kendi seçimlerine sayg duyma hem de kendinde amaç olarak değerlerinle bağdaşır șeyleri seçmemi sınırlandırma yükümlülügü altına yerleștirme (placing) becerisinde kabul edersem, seni aktif anlamda kendinde bir amaç olarak kabul etmem gerekir. Kendimizi karşıllıklı yasa yapma sistemi içerisinde bütünüyle bağlı olarak görme anlamına gelen șey budur. Eğer amaçlarınla ya da en azından senin için-iyi olan șeylerle mutlak bir șekilde iyi olarak ilgilenmekle yükümlüysem, seni pasif anlamıyla kendinde amaç olarak kabul etmem gerekir. Kant açık bir șekilde bu ikisinin aynı anlama geldiğini, yani pasif anlamında kendinde amaç olan herkesin aktif anlamında da kendinde amaç olması gerektiğini düșündü. Sadece insanlar ile ilgili düșündügün zaman bu fikirler pekala çok yakın görünür; çünkü amacının mutlak biçimde iyi olarak ele alınmasını talep etmen herkesin onu, kimi sebepler vererek ele alması gerektiğini talep etmendir ve bu șekilde davranman diğerleri için bir yasa yapacak ve karșılıklı yasa yapmaya katılacak pozisyona sahip olduğunu iddia etmendir. Ancak hayvanları düșündüğümüzde, bu iki fikrin aynı olmadığı açık hale gelir. Onlar için iyi olan șeyin mutlak olarak iyi olduğu anlamda kendilerinde amaç oldukları, ki karșılıklı yasa yapmaya bizimle birlikte katılmasalar bile, kesinlikle doğru olabilir (Korsgaard, 20I8, s. I4I). 
Korsgaard bu alıntıladığımız önemli pasajda, özel olarak tüm yaratıkların yani insanlar kadar diğer hayvanların da belli nihai iyilerle hareket ettikleri üzerinde durmaya çalıșır (Korsgaard, 20ı8, s. II3). Kant'ın kendinde amaca dair açıklamasını da bu kapsayıcılıkta iki türlü ele almamız gerektiğini söyler. İlkin insanlar otonom yasa koyucular olarak "Amaçlar Krallı̆̆g”"nda aktif anlamda kendinde amaç değeri tașırlar. Ötekinde ise insanlar hayvansallık bakımından kendinde bir amaç değeri taşırlar ve bu düzeyde insanlar pasif anlamda bir kendinde amaç değerine sahiptirler (Korsgaard, 20I8, s. I42).

Korsgaard sözünü ettiği bu aktif ve pasif kendinde amaç ayrımını șu șekilde de ifade edebileceğimizi belirtir: Bir karar vermenin, bir seçimde bulunmanın "iki görünümü (aspects) ya da "anı” (moment) bulunur. Birinci anlamında bir șeyi istemem, örneğin bahçede sebze büyütmeyi istememdir ve bu seçim benim için iyidir. Bu iyiyi nihai iyiye sahip bir yaratık olarak mutlak iyi olarak ele alabilir, benim için mutlak iyiymiş gibi kovalayabilirim. Bu benim için iyinin, mutlak bir iyi olması bakımından kendinde bir amaç olduğunu söyleyebilirim. İkinci anlamında ise bu iyiyi kendi gelecek benliğime bağlayacak bir yasada -Korsgaard'ın sebze büyütme örneğini devam ettirecek olursak- sebze büyütmek için toprağ sulama yükümlülüğünü bir kategorik buyruk/imperatif olarak kendime yükleyebilirim. Hislerime, arzularıma koșullu olmayan bu yarattığım yükümlülük, yani belli bir sebeple ve yasa ile davranmam, "seçimlerimi yasa olarak almak" kișilerin otonomime saygı göstermesini gerektiren bir durumdur. İște bu ikinci düzeyde akılsal varlıklarla ilișki kurar, herkes için yasa yapan bir otonom yasa koyuculuğu gösteririm (Korsgaard, 20I8, s. I43-I44). Seçtiğim șeyle bu düzeydeki bir değer ilișkisi, Korsgaard'ın ifadesi ile diğer bir anlamda yani aktif anlamda kendinde bir amaç olduğum anlamina gelir.

Korsgaard yukarıda üzerinde durduğu ayrımda, Kantçı bağlamda değer ve değer verme ilișkisine odaklanır; kendimize ve kendimizle birlikte diğerlerine değer vermenin ikili sferi, uzamı üzerinde durur. Birinci uzamda tüm hayvanların kendilerine göre belli iyiler söz konusu iken, ikinci düzeyde ise kendi iyimin herkes için geçerli olacağı evrensellik ve mutlak iyiler geçerlidir. Akılsal insan, salt birinci düzeyde hareket eden insan olmayan hayvanlardan farklı olarak bu iki uzamı da kapsayacak bir 
yasallıkla hareket ederek, her iki düzeyi de kendinde amaç olarak ele alabilir. İște Korsgaard'a göre Kant'ın felsefesini bu anlayıșa uygun okuyabiliriz. Çünkü Kant (değeri bizzat șeylerin kendisinde arayan teorisyenlerden farklı olarak) belli bir bilgi yönü olan değeri kișide arar, değer vermeyi bizlere göreli bir șekilde ele alır. İyi benim için iyi olandır (Korsgaard, 20I8, s. 135) ve akılsal olması bakımından söz konusu iyinin ișleyișini insanda en bașarılı kılan ise insanın eylemlerine ve amaçlarına mutlak bir değer vermesi, akılsal seçiminde diğerlerini kendinde amaç olarak gözetmesidir. İnsanın eylemini gerçek anlamda akılsal ve iyi kılan, "ilkeni evrensel bir yasa olarak istemelisin” kategorik buyruğudur (Korsgaard, 20I8, s. I40). Kant bu buyruğu șu șekilde ifade eder: "ancak aynı zamanda genel bir yasa olmasını isteyebileceğin maksime göre eylemde bulun.” (Kant, 2002, s. 38). Bu kategorik buyrukta da bir eylemin herkes tarafindan kabul edileceği, herkesin hemfikir olacağı bir doğruluk söz konusudur (Korsgaard, 20I8, s. I4O-I4I). Ve akılsal biçimde kendi ilgimizi diğerlerine genișlettiğimiz bu bakıșı, ilk düzeyde belli bir değere sahip olduğunu gördüğümüz ve paylaștı̆̆ımız, bizler gibi akılsal olmayan hayvanlara da genișletebiliriz. Hayvanların bakıs, açısından bakan bir sempati ile hareket ettiğimiz takdirde ise her yaratığa öncelikli olarak haz ve acı ya da içsel değeri ile değil, değerin bir kaynağı olduğunu gözeterek bakabilir ve onların iyi ya da kötüsüne de değerin değer verenden geldiğini kabul ederek mutlak anlamda, kendinde amaç olarak yaklaşabiliriz (Korsgaard, 20ı8, s. I36-ı37). $\mathrm{Bu}$ yolla da aslında tüm iyilerimize, yani bedensel ve akılsal iyilerimize daha kapsayıcı yaklașır, kendi değerimizi daha tam/bütünlüklü kavrar (Korsgaard, 20I8, s. I44), “insanlığımız”ı daha tam gerçekleștiririz (Korsgaard, 2018, s. I45). ${ }^{20}$

Korsgaard tüm bu açıklamaları sonrasında ahlakı, "bir hayvan olmanın sadece insani bir yolu" olarak nitelendirir. Ona göre bizler "ahlaki yasa yapma içerisinde belli bir yolda hayvani doğanın kendi değerini zaten onaylıyoruzdur." (Korsgaard, 20ı8, s. I46). Kant'ın iddia ettiği gibi, akılsal otonom varlıklar olarak birbirimize yüklediğimiz yükümlülüklerimiz karș11klı yasa yapmaya, birbirimiz üzerinde benzer iddialarda bulunmaya

\footnotetext{
${ }^{20}$ Ona göre aslında Kant da sözünü ettiği kimi sorunlara rağmen "İnsanlık Formülü" altında yardımseverlikten (beneficence) bahsederken her iki yönümüze, yani akılsal ve hayvani doğamızı içeren bir saygıdan bahseder (Korsgaard, 2018, s. I45).
} 
dayanır. Fakat hayvanlarla belli ortaklıklarımız var ve bu ortaklığa bağlı hayvansallık düzeyinde de belli iyi ve kötü șeylerden bahsedebiliyoruz. İște hayvanlarla olan bu ortaklığımız, hayvanlara yönelik gerçekleștirebileceğimiz kimi yükümlülüklerimizin olduğunu bize hatırlatır, bizi hayvanlara karșı kimi yükümlülüklere sevk eder. İleride söz edeceğimiz tüm bu yükümlülükler, kimi iyilerin tüm hayvanlar ve insanlar için nihai ve mutlak iyi olduğu ve bu bakımdan da kendinde bir amaç değeri tașıdığı bir zeminde yükselir (Korsgaard, 20ı8, s. I47). Pasif ve aktif kendinde amaç ayrımı ile söylersek, bu yükümlülükler pasif anlamda amaçsallığımızı kapsayan bir ilișkiler içerisinde yükselirler.

Sonuç olarak Korsgaard tüm bu açıklamalarıla Kant'ın insanlar ile hayvanlar arasındaki keskin ayrımını yumușatmaya, revize ve reforme etmeye çalıșır. Bu ilișkiselliği salt akılsallık üzerinden ele almak yerine (üzerinde durduğumuz aktif ve pasif kendinde amaç ayrımı gibi kimi nüanslarla) hayvanları da ahlaki topluluğun içerisine dahil etmeyi ister. Onları kendilerinde amaç durumundaki yoldaș yaratıklar olarak ele alabileceğimizi belirtir (Korsgaard, 20ı8, s. I48). Ona göre hayvanlarla ilișkilerimizin farklı yükümlülükler temeline sahip olmaları, hayvanlarla aynı topluluk içerisinde yer almamızın önüne geçmemelidir (Korsgaard, 20I8, s. I48I49). En yüksek iyi olarak kabul edebileceğimizi belirttiği "Amaçlar Krallı̆̆ı"nı "tüm iyi amaçların bütünü”nü kapsayan bir ilișkisellikle ele almamız pekala mümkündür. Hayvanların da içinde yer aldığı böyle bir krallık, herkesin iyisini gerçekleștirebileceği, dünyanın tüm yaratıkları için daha iyi yașanabilir bir yer olabilir (Korsgaard, 2018, s. 153).

Gelgelelim Korsgaard'ın samimi bir șekilde belirttiği gibi, böyle bir yașam yolunda ciddi kimi zorluklarla karșılașabiliriz. Örneğin hayvanların doğa sisteminin içerisinde kök salmıș durumlar nedeniyle sahip oldukları ilgileri/çıkarları ile bir hayvan olarak bizim ilgilerimiz/çıkarlarımız farklı olabilir. Çıkarlarımız, “dünya kaynakları” ve "doğal ortam” konusunda bizi "rekabete zorlayabilir". Ayrıca çoğu hayvan gezegen için sayıca çok fazla doğum yapabilmekte ve bu doğanların büyük kısmı da varolușunun güzelliklerini yașayacak bir duruma gelmeden önce ölmekte, öldürülmektedir (Korsgaard, 20I8, s. I54). Yine Korsgaard'ın haklı olarak vurguladığı üzere doğanın "ahlaki standartlar karșısında dik kafalı/itaatsiz" bir durușu vardır. Kendi eylemlerimize yüklediğimiz yasayı, iyi formunu doğaya yüklememiz 
pek de mümkün değildir (Korsgaard, 2018, s. 154). Durum buyken bizlerin doğadaki kimi çatıșmalar içerisinde doğru olan șeyleri yapması gerçekten zor olabilir. Gelgelelim Korsgaard yașamın tüm bu zorluklarına rağmen insandan umudunu kesmez. Herkesi, hiçbir zarar vermeden söz konusu "Amaçlar Krallı̆̆ı" içerisine dahil edebileceğimize, bu krallık kapısını herkes için açık tutabileceğimize inanır (Korsgaard, 20ı8, s. 155).

Korsgaard bu 'iyimser umut' içerisinde, özellikle Kant'in epistemik ılımlılığını hatırlamamızı ister. Ona göre Kant felsefi olarak en temelde doğadaki yerimizi, sınırlarımızı tespit etmeye çalıșır ve bu sorușturmasında bizlerin doğanın kendinde bilgisine sahip olabileceğimizi düșünmez. Kant insanlığımızdan kaynaklanan bu sınırlılıklarımız içerisinde akılsal varlıklar olarak teorik anlama ve ahlaki eylem kapasitelerimiz ile dünyayı daha bilinebilir ve akılsal kılacağımıza inanır. Ama sözünü ettiği ahlaki yasaların șeylerin doğalarında yazılı bulunmadığını, onların salt bizim yasalarımız olduğunu da ekler (Korsgaard, 20I8, s. I69). İște Korsgaard sahip çıktığı bu Kantçı anlayıșın, bizi diğer yaratıklardan daha eșsiz bir yerde tutmadığına inanır. Harika bir șekilde belirttiği gibi, "bizler evrenin sevgilileri değiliz, yazgımız yazgıları bize benzer biçimde kendi varolușlarını deneyimlemek olan diğer yaratıkların yazgılarından mutlak biçimde daha önemli değildir. Aksine tam tersidir.” (Korsgaard, 20ı8, s. I69). Bizleri özel kılan șey söz konusu ahlaki önemlilik değil, diğer yaratıkların bizler kadar değerli olduğunu kavrayacak "empati”ye sahip olmamız ve aklımızla hayvanları da kendinde amaç alacağımız bir sonuca gidebilmemizdir (Korsgaard, 20I8, s. I69). Odaklanmamız gereken bu özelliğimizdir. Coetzee'nin The Lives of Animals'daki karakteri olan Costello üzerinden belirttiği șekilde, diğer insanlara ve hayvanlara yönelik yapmamız gereken șey onların varlığını görebileceğimiz bir șekilde yüreğin (heart) konumlandığı "sempati/duygudașlik" yetisine dikkat etmemiz ve onu kapamamamızdır (Coetzee, I999, s. 34-35).

Pekala biz akılsal insanlar yüreklerimizi de kapamadığımız takdirde, hayvanlara yönelik ne gibi yükümlülükleri yerine getirebiliriz? Korsgaard ile bir sonraki bölümde bu soruya cevap vermeye çalıșalım.

\section{Hayvanlara Karșı Yerine Getirebileceğimiz Kimi Yükümlülükler}

Korsgaard yukarıda gördügümüz açıklamalarını ideal bir teori düzle- 
minde götürür, hayvan etiğinin pratik sorunlarına girmez. Ele aldığı sorunlara Kant'ın ahlaki bir ideal teori olarak kabul ettiği “Amaçlar Krallı̆̆ı” gibi yaklașır. Çünkü Rawls'a benzer bir șekilde ideal bir durum içerisinde hangi adalet ilkesini belirlemenin daha doğru olacağını ve ancak bu süreçten sonra kötülükle mücadele etmek için kimi ilkeleri geliștirebileceğimizi vurgular (Korsgaard, 20I8, s. I5I, I55). Bir bakıma sunduğu șey, hayvan etiğinin ideal bir teorisidir ve bu teori ile kimi ilkeleri, örneğin ne gibi ilkeler geliștirebileceğimizi düșünmemizi ister. Önerisi Singer gibi faydacı değil Kantçı yani deontolojisttir; Kant gibi en yüksek iyiyi salt gayesi ile birlikte ele almaz, ahlaki bir eylem temelinde eylemimizin amacını seçeceğimizi düșünür (Korsgaard, 20I8, s. 155).

Dolayısıyla hayvanlara karșı yükümlülüklerimiz konusunda öncelikle onların kendilerinde amaç değerini kabul ederek ilerler (Korsgaard, 20ı8, s. 155). Hayvanları faydacıların değerlendirdiği tarzda salt haz ve acı kapasitesi temelinde ele almaz, tek bașına hazzı ve acıyı iyi ve kötü olarak değil, Aristotelesçi bir çizgide iyiyle birlikte düșünür (Korsgaard, 20ı8, s.156-157). Örneğin ona göre "bir yaratı̆̆ın nihai iyisi, bilinçli bir iyi ișlev görmesi”, bu işlevlerini iyi bir șekilde gerçekleștireceği bir koșulda olmasıdır, diğer bir deyișle salt haz ve acı yokluğuyla ilgili değildir. Haz "iyiye yönelik bir farkındalık, algı" iken acı ise bunun tersi yani "iyiyi azaltan șeye dair bir algı"dır (Korsgaard, 20I8, s. I62-I63). Bu durumda haz ve ac1, bilincin nihai iyideki kurucu rolü içerisinde bir farkındalık sağlarlar (Korsgaard, 20I8, s. I63). Bu anlayıs, temelinde Korsgaard'ın hayvanları ele alması, hazzı maksimize etmeyi amaçlayan hazcılar ya da sonuççulardan farklı olarak- gördüğümüz gibi- Kantçı ve Aristotelesçi bir çizgide akılsallığa dayanır (Korsgaard, 20I8, s. I58) ${ }^{2 \mathrm{I}}$, hayvanları koșulsuz bir șekilde kendinde bir amaç olarak alacağımız bir akılsallık üzerinde durur.

${ }^{21}$ Korsgaard'a göre Singer böyle düşünür. Çünkü Singer için "kendilik-bilinci" olmayan hayvanlar, iyi için salt 'kaplardırlar' (receptable)", (Korsgaard, 20I8, s. 159). Örneğin beslediğimiz bir köpeğin kaybından sonra bașka bir köpeği sahiplenebilecek ve bu tarz iyi deneyimler varlığını sürdürmeye devam edecektir. Korsgaard, Singer'ın sözünü ettiği kızının köpeğinin karșılașacağı ölümü böyle ele almakla "onun deneyimlerinin iyisini" "kendisi için" ele almadığını, bunu sorun olarak görmediğini belirtir. Singer için önemli olan "dünyada bir yerlerde devam etmekte olan kimi iyi deneyimlerin" varlığıdır (Korsgaard, 20ı8, s. 159). Singer açısından "duyarlı varlıklar değerli bir șeyin kaplarıdırlar, içeriği dökülmeden transfer edilen diğer kap olduğu müddetçe bir kabın kırılması sorun değildir.” (Akt. Korsgaard, 2018, s. 159). Korsgaard'ın üzerinde duramayacağımız bu eleștirileri ve faydacılıkla kendi haz ve acı anlayışına yönelik farklılıkları için (bkz. Korsgaard, 20ı8, s. 155-170). 
Korsgaard, Aristoteles ile beslenen söz konusu Kantçı teorik açıklamalarına paralel olarak hayvanlara yönelik kimi pratik konulara da değinir. Fellow Creatures: Our Obligations to the Other Animals'ın son üç bölümünde hayvanlara karșı ne gibi yükümlülüklerimizin olabileceğini tartıșır. Bu tartıșmasını "bomo sapiens”in türlerin soyunun tükenmesinin baș sorumlusu olduğu (Korsgaard, 20I8, s. I9I) gerçeğiyle yürütür. Öncelikli olarak hayvanlara yönelik yükümlülüklerimiz konusunda iki karșit görüșe dikkat çeker. Bu görüșlerin bir tarafında Korsgaard'ın “yaratıcı etikçiler” (creation ethicists) adını verdiği bir grup vardır ve bu grup avlanmaya ihtiyaç duymayan bir șekilde, evrim zincirine müdahale ederek avcı hayvanlar türüne son verme ve tüm hayvanları evcilleștirme talebinde bulunur. Bunun karșısında yer alan grup ise "kölelik karșıtı olanlar"dır (abolitionists) (adını Amerika'daki Sivil Savaș öncesi kölelik karșıtlarından almaktadır (Korsgaard, 20I8, s. I75). Bu grup avcılığa müdahale etmemiz ve adım adım evcil hayvanlar da dahil tüm hayvanları serbest ve yalnız bırakmamız gerektiğini söyler (Korsgaard, 20I8, s. I73).

$\mathrm{Bu}$ iki gruptan ilkine giren McMahan New York Times'daki “The Meat Eaters" makalesinde, etçil hayvanların soyunun giderek tükenmesinin, genetik müdahalelerle etçil kimi türleri otçul türe dönüștürmenin iyi bir șey olacağını, bunun dünyayı daha iyi bir yer kılacağını söyleyebilmektedir (Korsgaard, 20I8, s. I74). ${ }^{22}$ McMahan'in bu ilginç talebinin arkasında șu barışçıl isteği yatar: "Bir dünya tasarlayacak ve yaratacak bir durumda olsaydım... bu dünyayı tüm bilinçli bireylerin diğer bilinçli bireylere eziyet etmeden, onları öldürmeden hayatta kalacakları șekilde düzenlemeye çalıșırdım. Çoğu insanın da aynısını yapacağını ümit ediyorum.” (akt. Korsgaard, 20ı8, s. I74). Açıkçası McMahan 1srarlı olmadığı bir akıl yürütme içerisinde ele aldığı bu açıklamalarının, yani avcıların türünü ortadan kaldırma önerisinin haklı olarak Tanrı'yı oynamak olarak görülebileceğinin farkındadır. Ama bu sorunların hepimizin sorunları olduğuna ve bizlerin birçok türün soyunun tükenmesine neden olduğumuza ve istedi-

${ }^{22}$ Korsgaard, McMahan'ın aslında üzerinde akıl yürüttüğ̈ ve kimilerine çekici gelecek bu durumu güçlü bir șekilde önermediğine, çünkü bu durumun "Maltusçu bir karșı ütopya”, yani ot oburlarda așırı bir nüfus artıșına ve beraberinde de yiyecek kaynakları nedeniyle açlıktan ölümlerin gerçekleșeceği sonucuna dikkat çeker. Ama doğum kontrolü gibi yollarla otobur nüfusunu dengelemek kimileri için McMahan'in üzerinde durduğu açılamayı savunmayı beraberinde getirebilecektir (Korsgaard, 20I8, s. I74-I75). 
ğimiz șekilde doğal dünyanın yapısını șekillendirmeye çalıștığımıza dikkat çeker (Korsgaard, 20I8, s. I83). Yani aslında insanın özellikle son dönemlerde zaten Tanrı'yı oynadığını ve kendisinin de bașka bir șeyi yapmadığını belirtmeye çalıșır. Açıkçası bu düșüncede güçlü bir haklılık payı vardır. ${ }^{23}$

Yaratıcı etikçilerden farklı olarak Kantçı çizgide hareket eden "kölelik karșıtları" ise hayvanları ev hayvanı (pet) olarak ele almayı doğru bulmazlar. Bu çizgiyle ortak bir yaklaşıma sahip Regan gibi filozoflar için sorun, hayvanların acı çekmesi ya da onlara acı vermemiz değil onları bir araç, kendimiz için bir kaynak olarak görmemizdir, sorun bizzat böyle bir sistemin kendisidir (Korsgaard, 20I8, s. 176). Bu vurgu doğrultusunda kölelik karșıtları köpeklerin arama, kurtarma ve körler için görme gibi nedenlerle kullanımlarına, maymunların engelliler ve genel anlamda hayvanların televizyon eğlenceleri için kullanımlarına karșıdırlar (Korsgaard, 2008, s. 176). Kölelik karșıtları hayvanları kendinde amaç olarak ele almanın zor olduğunu gördüklerinden onlara müdahale etmememiz, onlardan uzak durmamız gerektiğini belirtirler (Korsgaard, 20I8, s. 178 ). ${ }^{24}$

$\mathrm{Bu}$ açıklamaları, ses getiren eylemleriyle bildiğimiz PETA'da (People for the Ethical Treatment) da görebiliriz. PETA, kölelik karșıtlarının izinde hayvanlara sahip olmanın șu sonuçlarını eleștiri konusu yapar: Hayvanları evcilleștirmek aşırı bir evcil hayvan nüfusu yaratmakta ve bu kalabalık içerisinde istemediklerimizi "așırılık" görerek yok etme yoluna gitmekteyiz. Alışverișin bir parçası haline gelen hayvanlara sahip olma ve onların sevgilerini isteme bencilliği sonucunda eve hapsedilen hayvanlar, doğal davranışlarını kaybederek salt bizim izin verdiğimiz sınırlar içerisinde hareket ederler. Evde yașama șansına sahip olmayan milyonlarca köpeğin durumu ise daha da kötüdür, zincire bağlı duran sayısız köpek salt dünyayı izlemekle yetinmektedir. Köpekler bebeklikten itibaren tutuldukları kirli kafeslerde satın alınmadıkları takdirde öldürülmekte, barınaklarda suskun bir şekilde tutulmaktadırlar. Birçoğu canı sıkılmış çocuklar tarafından dövülmeleri, yakılmaları tarzında sayısız kötülüklere maruz kalabilmekte-

${ }^{23}$ İnsanın giderek nasıl Tanrı'nın rolünü üstlendiğine dair popüler ve etkileyici bir okuma için (bkz. Harari, 2015).

${ }^{24}$ Korsgaard'n dikkat çektiği gibi insanların birbirleriyle ilișkileri salt amaç ilișkisine dayanmaz, araçsal ilişkiler de kurarız. Ama bu tür ilişkilerde Kant'ın vurguladığı rıza önemlidir, kișinin rızasının özgür, bilgilendirilmiș ve zorlanmamıș olması gerekir. Hayvanlar ise böyle bir șansa sahip değildirler (Korsgaard, 20I8, s. I77-178). 
dir. İște kölelik karșıtları ve PETA tarzında gruplar sözünü ettikleri önemli nedenlerle, insanların ve hayvanların eșit ama birbirlerinden ayrı bir șekilde yașamaları gerektiğini düșünürler (Korsgaard, 20ı8, s. I79). Yani bu grup yaratıcı etikçilerin tüm hayvanları evcil kılma isteklerinden farklı olarak, tüm hayvanların yabani olmasını talep eder bir çizgide ilerler (Korsgaard, 2018, s. I80).

Hayvanlar konusunda ciddiye alınması gereken öneriler ortaya koyan bu iki grup içerisinde Clare Palmer gibi daha melez düșünceler öne sürenler de olmuștur. Palmer'a göre yabani hayvanların doğal kötülüklerle ilgili durumlarına karşı hiçbir sorumluluğumuz olmamalıdır; ama onlara yönelik kendimizin sebep olduğu kötülüklerden, zararlardan sorumlu olmamız gerekir. Palmer'ın bu sağduyulu açıklamaları vahși hayvanlarla ilgilidir. Kendisi evcil hayvanlarla ilgili daha farklı düșünür, her durumda onları korumamız ve onlara yardım etmemiz gerektiğini söyler. Çünkü, haklı olarak belirttiği gibi, bizler evcil hayvanları kendimiz için varoluşa getiririz ve onların yetișmesini/üremesini kontrol ederiz. Tüm bu durumlar hayvanları savunmasız kılar ve onların bize fazlasıyla bağımlı olmalarına yol açar (Korsgaard, 20I8, s. I82-I83). Dolayısıyla hayvanların sebep olduğumuz savunmasızlıklarına ve bağımlılıklarına karșı yerine getirmemiz gereken kimi önemli yükümlülüklerimiz vardır.

İmdi Korsgaard tüm bu açıklamalar içerisinde kendini Palmer'ın değerlendirmelerine daha yakın hisseder ve özellikle McMahan'in açıklamalarına șüpheyle yaklașır. Ona göre McMahan bilinçli bir hayvanın diğerini öldürmeden yașamasına dair düșüncesinde kușkusuz haklıdır (Korsgaard, 20I8, s. I85), ama bu düșünce yani avcı hayvanları evrim zincirinden uzaklaștırmak ya da onları dönüștürmek bütün hayvanlar üzerinde radikal bir dönüșüm yaratabilir, onların doğalarına bağlı iyilerini değiștirebilir. Bu risk karșısında kendisi ahlaki ve biyoçeșitlilik bakıș açısından yaratıcı bir etikten ziyade "koruyucu etik" (preservation ethics) dediği yaklașımın, yani yeni bir hayvan türü yerine var olan hayvan topluluklarını korumaya çalıșmanın daha uygun olduğuna inanır (Korsgaard, 20I8, s. 2I8). Tüm var olan türlere yönelik bir koruyucu bakıș açısı tașır ve özellikle evcil hayvanlar konusunda, Palmer gibi, hayvanların büyümesini kontrol etmemiz nedeniyle onların iyi bir șekilde büyümesi için kimi ödevlerimiz ve yükümlülüklerimiz olduğunu düșünür (Korsgaard, 20I8, s. I86-I87). 
Korsgaard'ın pozisyonunu ortaya koyduğu bu tartışmalar içerisinde, hayvanlara yönelik yükümlülükler konusunda ilk dikkat çektiği konu ise hayvanların iyi bir șekilde yașamalarını sağlayan doğal ortamdır (babitat). Korsgaard'a göre doğal ortam, bireysel/tek bașına dolașan hayvanlar için tür ve üyesi arasındaki ilișkiye benzerdir. Hayvanlar yașamalarını, üremelerini sağlayan belli bir ortamda ve topluluk içerisinde yaşarlar ve bu topluluğun bir üyesi olarak da iyileri durumunda olan, onları mutlu edecek ișlevlerini yerine getirirler. Dolayısıyla doğal ortam bir popülasyon olan türlerin ve bu türlerin üyesi durumunda olan bireylerin "ortak iyisi” durumundadır; yani hayvanlar için olmazsa olmazdır. Böyle bir olgu karșısında biz insanların hayvanlara yönelik önemli ödevi ise onların doğal ortamlarına saygı göstermek, onların doğal ortamlarında yașamalarına izin vermektir. Özellikle bu uğurda ve gelecek kușaklarımız için gezegeni kirletmemek ve onu 1sıtmamak öncelikli ödevimiz olmalıdır (Korsgaard, 20ı8, s. 206-207). Bu yükümlülüğe önem vermediğimiz süre içerisinde hayvanların yașam alanlarını tahrip etmemiz kaçınılmaz olacaktır. Yapılacak șey bu iken onların yașam alanlarını yok edip, sonra soyu tükenme tehlikesiyle yüz yüze gelen kimi hayvanları biyoçeșitliliği korumak adına hayvanat bahçesinde tutmak doğru bir yol değildir. Hayvanları doğal ortamlarından uzaklaștıran bu yöntem yerine, yakın bir gelecekte tekrardan doğal ortamlarını inșa etmeye çalıșmamız daha hakkaniyetli bir yol olacaktır (Korsgaard, 2018, 207-208).

Korsgaard hayvanlara, özellikle vahși hayvanların doğal ortamlarını yeniden inșa edip, onlara bu amaç doğrultusunda yer bırakmanın diğer bir görevimiz olduğunu belirtir; çünkü gezegenin sadece bizim olmadığını hatırlamamız gerektiğini söyler. Korsgaard'ın biyolog E.O. Wilson üzerinden belirttiğine göre, gezegenin yarısı bile ekosistemin ve türlerin büyük bir kısmının korunması için yeterli olabilecektir (Korsgaard, 20ı8, s. I96). Çevrenin korunması ve biyoçeșitlilik gibi hassasiyetleri gözeten ve gelecek kușakları da unutmadan daha yüksek bir yașam niteliği ve daha hakkaniyetli bir ideal dünyayı inșa etmek için gezegendeki popülasyonumuza, gerekli kaynaklara dikkat etmemiz hayati bir öneme sahiptir (Korsgaard, 2018, s. 209, 216).

Korsgaard'ın bu husus kadar önemle üzerinde durduğu diğer bir nokta ise insanların dünyanın kaynaklarını dengesiz bir șekilde tüketmeleri- 
dir. Verdiği bilgiye göre 2012 verileriyle bir Amerikalı 4.I büyüklügüünde dünya kaynaklarıyla, bir Fransız 2.5 büyüklügünde dünya kaynaklarıyla, yani dünya sınırının çok üstünde yașamlarını sürdürmektedir. Böylesine bir tüketim dengesizliğinde kendilerini hayvanlardan daha önemli düșünen insanların, sözünü ettiği ideal bir yașam yolunda toprakların bazılarını hayvanlara geri vermeleri çok zor olabilecektir. Korsgaard Birleșmiș Milletler Yiyecek ve Kültür Organizasyonu'nun verilerinin bu durumu aslında mümkün kıldığını belirtir. Yine verilere göre dünya tarım arazisinin yüzde 26'sı çiftlik hayvanlarının besinleri için kullanılmaktadır. Bu arazilerin bir kısmının hayvan besini yerine insanların yiyecekleri, örneğin meyve-sebze için kullanıldığı bir durumda bile, hem daha çok insanın beslenmesi gerçekleșecek hem de sözünü ettiği vahși hayvanlar için birçok toprak arazisi boș kalacaktır. Dolayısıyla bu kolay ve işlevsel görünen amaç doğrultusunda Korsgaard adına yapılması gereken șey, et yemeyi ve hayvan ürünlerini kullanmayı bırakmak olmalıdır. Bunu yapmamız, istismara uğrayan ve yenen evcil hayvanlar kadar iklim ve biyoçeșitlilik için de bir kazanım olacaktır (Korsgaard, 20ı8, s. 2IO-2II). Bu uğurda yașamlarını yașamaya değer bulmadığımız evcil hayvanları dünyaya getirmemek özellikle çok hayatidir (Korsgaard, 2018, s. 219).

Gelgelelim bugün için bu vicdani taleplere hala çok uzağız. Yaşamlarımız hayvanlara yönelik araçsal yaklașımımız hala akla gelmeyecek kötülükler ve acılarla doludur. Korsgaard'ın da dikkat çektiği gibi, Singer etkileyici eseri Hayvan Özgürleșmesi’nde (Animal Liberation) insanların fabrikaçiftlik hayvanlarından civcivlere, tavuklara, domuzlara ve ineklere-insanı insanlı̆̆ından utandıracak- ne gibi acılar çektirdiğini ne gibi kötülükler yaptığını tüm çıplaklığıyla ortaya koyar (Korsgaard, 20I8, s. 220). Örneğin tüm hayvanların yüzde 98 'ini olușturan bu çiftlik hayvanlarının binlercesi her gün öldürülmektedir. Sadece Amerika Birleșik Devletleri'nde her gün 23 milyon tavuk (yani her saniyede 266 tane) ve 268 bin domuz katledilmektedir (Korsgaard, 20I8, s. 22I). ${ }^{25}$ Az önce dikkat çektiğimiz gibi, bu çiftlik hayvanlarının beslenmeleri için toprakların üçte biri kullanılmakta ve sera gazının yüzde 3o'u bu sürece bağlı olarak salınmaktadır, yani tüm ulașım sektöründen daha fazla çevreye zarar veren bir durum söz konusudur. Bu besi hayvanları ve ürünleri, Dünya Çevre Gözlem Enstitüsü'ne

${ }^{25}$ Singer'ın ayrıntısına giremeyeceğimiz bu etkileyici bașyapıtı için (bkz. Singer, 2005). 
göre, yıllık gaz-salınımının yüzde 5r'ini olușturmaktadır. Böyle bir durumda çiftlik hayvancılı̆̆ı biyoçeșitlilik ve iklim çeşitliliği için sorun yaratan ana nedenlerden biridir (Korsgaard, 20I8, s. 222). Dolayisiyla bu olgu karșisında vejetaryen ya da vegan olmasak bile fabrika çiftliklerinden bir șey satın almayı reddetmenin bu sürecin değișmesine büyük katkı sağlayacağı açıktır (Korsgaard, 20I8, s. 222).

Korsgaard'ın haklı olarak belirttiği gibi, bu hassasiyeti gözeten insanlar nedeniyle hayvanların istismar edilmediği çiftlikler kurulabilmiștir. Gelgelelim fabrika çiftliklerinden rahatsız olan bu kișiler temel olarak acı çekmeye odaklanmıșlardır. Birçoğu acı çekmenin hayvan için kötü olduğunu düşünerek hareket ederler. Buna bağlı olarak da bir hayvanın acı çekmeden ölmesinin bir insanın ölümü kadar sorun olmayacağına inanırlar. Kimi filozoflar da bu inancı paylașır; çünkü bu filozoflar hayvanların anı yaşadıklarını, zamana yayılan bir benlik kavramına ve bilincine sahip olmadıklarını düșünürler (Korsgaard, 20I8, s. 223) ve düșüncelerine bağlı olarak da hayvanların ölümünden ziyade hayvanların acı çekmemesi üzerinde dururlar. Korsgaard'a göre Singer da bu bakıș açısıyla yani öncelikli olarak hazza odaklandığından bu gibi çiftliklerde temel meseleye, öldürmek olarak değil birinin yerine diğerinin geçeceği bir yer değiștirme șeklinde yaklașır. Singer için "hayvan salt deneyimin gerçekleștiği bir yerdir". Bir faydacı olarak onun adına temel sorun, hazzın dünyadaki miktarını azaltmamaktır (Korsgaard, 2018, s. 223-224).

Ancak daha önce de belirttiğimiz gibi, Korsgaard tüm duygusal hayvanların çeșitli derecelerde ve zamana yayılan bir kendilik-bilinçleri olduğunu düșünür. Hazzı ve acıyı da kișisel görür, onları belli bir hayvanın hazzı ve acısı olarak ele alır. Bu anlayışına bağlı olarak da hayvanı yemek için öldürmenin hayvanı her durumda iyisinden yoksun bırakmak anlamına geleceğini belirtir (Korsgaard, 2018, s. 223-224). Dolayısıyla kendisi insani çiftliklerin fabrika çiftlikleri kadar kötü olmadığını düșünse bile, bu düșüncenin ilgili çiftliklerin var olma gerekçesini bize veremeyeceğini söyler (Korsgaard, 2018, s. 225). Bu noktada eklememiz gereken bir șey de insani çiftliklerin hayvanın doğal bir șekilde yașamasına izin verseler de fabrika çiftlikleriyle ortak olarak paylaștıkları șeydir. Her iki çiftlikte de hayvanlar, et için yenecek noktaya geldiklerinde öldürülecektir; yani tüm bu çiftliklerde hayvanların yaşamları çok kısa olacak, hayvanların hepsi 
büyüdüklerinde akșam yemeği için bekletilmeden öldürülecektir. Fabrika çiftliklerinde bu ölümün mümkün olduğunca erken gerçekleșmesi, Singer'ın vurguladığı gibi, șanslı bir durum olacaktır (Korsgaard, 20ı8, s. 225).

Korsgaard'ın pratik sorunlar ıșığında dikkat çektiği diğer konular ise hayvanların askeri amaçlarda ve bilimsel deneylerde kullanılmaları ve yoldaș hayvanlara yönelik sorunlardır. İlkini ele alırsak, Korsgaard haklı olarak, atlar ve köpekler gibi hayvanların geçmişte askeri amaçlar için kullanıldıklarını belirtir. Bugün özellikle köpekler insanların sahip olmadıkları özel becerileri nedeniyle askeri görevlerin önemli bir parçası durumundadırlar. Korsgaard'ın kölelik karșıtları üzerinden belirttiği üzere, köpeklerin bu görev konusunda rızalarını almamız mümkün değildir. Ancak kendisi bu hayvanların ilgilerini, yasa ile koruduğumuz ve onları bir mal gibi ele almayıp popülasyonumuzun bir parçası kıldığımız takdirde, adil bir savașın ve görevin bir parçası olabileceklerini ve bu durumu ahlaki olarak gerekçelendirebileceğimizi belirtir (Korsgaard, 20I8, s. 226-227). ${ }^{26}$ Yani bu hayvanlar belli bir ülke yurttașının bireyleri gibi değer görerek ülke için kimi görevlerin bir parçası olabilirler.

Korsgaard'ın üzerinde durduğu diğer bir konu ise hayvanların bilimsel olarak kullanılmalarıdır. Kendisi bu testleri kesinlikle kabul edilebilir bulmaz. Hayvanlar için ölümcül, istilacı olan bu testlerin, onları salt araç biçiminde gören barbarca eylemler olduğunu düșünür. Kendisinden farklı olarak testlere destek verenlerin temel gerekçesi ise, bu araștırmaların insan yașamını kurtardığını düșünmeleridir. ${ }^{27}$ Ancak Korsgaard'ın belirtti-

${ }^{26}$ Fakat bu durum II. Dünya Savașında yine köpekler gibi becerileri nedeniyle kullanılan yunuslar ve denizaslanları için biraz daha farklıdır. Çünkü bu vahși hayvanların ülkeleri yoktur, açık denizlerde yașamaktadırlar. Dolayısıyla bu hayvanları kullanmak ahlaki olarak biraz daha sorunlu olacaktır (Korsgaard, 2018, s. 226-227).

${ }^{27} \mathrm{Bu}$ akıl yürütmeyi destekleyecek kimi argümanları Regan gibi hayvan etiğinin öncü isimleri de ileri sürebilmiștir. Regan bir bot örneği üzerinden șunu dile getirir: Bir cankurtaran botunda dört insanın ve bir köpeğin yer aldığı bir durumda feda edilecek olanın köpektir (Korsgaard, 20I8, s. 228-229). Bu argüman ister istemez hayvanlar üzerinde yapılan testleri gerekçelendirebilir; çünkü birisi hayvanlar üzerinde yapılan testlerin insanın yașamını kurtaracağını söyleyebilir. Oysa Korsgaard'ın dikkat çektiği gibi hayvanlar üzerinde gerçekleștirilen deneyler ile bot vakası benzer görülemez; laboratuvarda hayvanın salt araçsal kullanımı söz konusu iken ikincisinde bu söz konusu olmayabilir (Korsgaard, 20I8, s. 229). Ayrıca Singer'ın Regan'dan şu açıklamayı istemesi yerindedir: "Ölümcül-ama acısız- bir deneyde bir ya da daha fazla insanı kurtarmak için bir köpeğin bile kullanılmasına izin vermeyi reddetmen ile bir insanı kurtarmak için cankurtaran botundan bir milyon köpeği atma istekliliğin arasında açık çelișki...” (akt. Korsgaard, 20ı8, s. 229). Açıkçası Singer bu yerinde tespitle, Regan'ın bot örneği üzerinden verdiği cevapta insanı fazlasıyla merkeze 
ği gibi, herkesin sonunda ölümle yüzleșeceği gerçeği karșısında söz edilmesi gereken șey aslında yașamların kurtarılması değil uzatılmasıdır. Yani hayvanlar üzerinde yapılan testlerin temel nedeni yașam süresini uzatmak, yașam süresini uzatmanın yollarını aramaktır. Korsgaard adına yașamın iyi olduğu gerçeğine bağlı olarak bu yolda ilerlemeler de elbette ki karalanacak durumlar değildirler (Korsgaard, 2018, s. 228-230). Korsgaard bunları görmezden gelmez, ama bu testler için farklı alternatif yollar geliștirebileceğimize inanır. Talebi hayvanların kullanılmadığı yeni alternatif test yolları bulmaktır (Korsgaard, 20I8, s. 223). Kendisi bu alternatif test yollarının neler olabileceği konusunda bize bir șey söylemez. Açıklamalarıyla hayvanlara hassasiyet ve duyarlılık gösterebilecek kimi bilim adamlarını yeni arayış̧ara teșvik etmek ister. Korsgaard bilim adamlarını, hepimizi șu konuda sorumlu bir șekilde düșünmeye sevk etmeye çalıșır: Daha uzun yaşamak için daha ne kadar süre hayvanlar üzerinde deneyler yapma pratiğini sürdüreceğiz?

Korsgaard son olarak yoldaș hayvanlar, yani evde beslediğimiz hayvanlarla ilgili kimi pratik sorunlardan söz eder. Daha önce bahsettiğimiz gibi PETA ve kölelik karșıtları hayvanların istismarını engelleyemeyeceğimizi, onlara iyi bir yaşam veremeyeceğimizi düșünerek (Korsgaard, 20I8, s. 234-235) hayvanları evcilleștirmemize itiraz etmektedirler. Korsgaard ise vahşi hayvanlar söz konusu olduğunda bu açıklamalara yakın dursa da ev hayvanlarılla ilgili değerlendirmelerinde onlardan uzaklaşır. Çünkü bu hayvanların iyilerine, beslenmelerine ve karakteristik davranışlarını gerçekleștirmelerine katkı sağlayabileceğimizi düșünür (Korsgaard, 20I8, s. 233). Ayrıca vurguladığı gibi köpekler ve kediler, özellikle de köpekler insanlarla birlikte yașam süren bir evrim geçirmișlerdir. ${ }^{28}$ Yani bize bağl1lıkları kölelik karșıtlarının düșündügü gibi hiç de doğaya aykırı değildir. Hatta köpekler insanlarla vejetaryen ve vegan bir süreç içerisinde yașayabilirler. Et obur olan kediler için bu durum daha zor olsa da yapay etlerle bu sorun pekala çözülebilir (Korsgaard, 20I8, s. 235). Gelgelelim Korsgaard'a için vahşi olan kimi hayvanları köpekler ve kediler gibi evde tutmak doğru olmayacaktır. Çünkü evcilleștirilmesi mümkün olmayan vahși hayvanların agresiflikleri kontrol edilemeyeceği için bu hayvanlar bizler için

\footnotetext{
aldığına ișaret eder.

${ }^{28}$ Bu birliktelik Alfa Kurt (Alpha) (20I8) filminde ilgi çekici bir șekilde ișlenmektedir.
} 
tehlike yaratabilirler. Yine yeterince boș alan olmadıkça kușları ve kemirgenleri ev içerisinde küçük kafeslerde tutmak da uygun bir davranıș değildir (Korsgaard, 20I8, s. 235).

Korsgaard'ın ev hayvanlarıyla ilgili dikkat çektiği diğer bir önemli konu ise sahipleri öldükten sonra sahipsiz kalan köpeklerin ve evde beslediğimiz agresif köpeklerin durumudur. Öncelikle kendisinin belirttiği gibi, insanlar bu konuda hayvanlara göre daha șanslıdırlar. Çünkü kimi insanlar hoșgörü gösterilemeyecek bazı davranıșlar geliștirdiklerinde ve birine bağımlı kaldıklarında sosyal kurumların desteklerini yanlarında bulurlar. Oysa davranışı problemli hayvanlar için böyle kamusal kurumlar yoktur, dolayısıyla bu hayvanları öldürmek en iyi seçenek olarak durmaktadır. Ancak Korsgaard için bu kararı tek bașına hayvanların sahiplerine bırakmak da doğru olmayacaktır; çünkü kișiler yoktan sebeplerle evcil hayvanları için böyle bir kararı alabilirler. Bunu engellemenin yolu, evcil hayvana sahip olmaya izin veren bir toplumun hayvanların refahını düșünmesi ve bu uğurda yasal güçlerle iş birliği içerisinde denetleme mekanizmasına bașvurmasıdır (Korsgaard, 2018, s. 234).

Nihai olarak Korsgaard hayvanlarla ilișki kurmanın, onların düșüncelerini ve hislerini anlamaya çalışmanın iyi bir insan olmanın parçası olduğuna inanır (Korsgaard, 20I8, s. 237). Hayvansever, kedileriyle yașayan bir Kantçı olarak ahlakın bize kendi iyimizi mümkün olduğunca diğer yaratıklarla paylașılır kılma yükümlülüğü verdiğini, bu temelde bireysel hayvanları ve hayvan topluluklarını istismar etmememiz gerektiğini düșünür. Kendisi insanların hayvanlar karșısında dünyada daha fazla mutluluk üretecek üstünlükleri olduğunu kabul etmez (Korsgaard, 20I8, s. 213-2I4). Korsgaard adına yapmamız gereken șey, bu dünyada bir arada yașamanın, onu paylașmanın yollarını bulmaktır.

\section{Sonuç}

Korsgaard'ın hayvanlara yönelik ele aldığımız açıklamaları uzun yılları kapsayan soruşturmalarına dayanır. Hayvanlarla ilgili tartışmalara Kantçı bir perspektifle yaklașır. Bu yaklașım önemlidir. Çünkü etik yaklașımların “çoğulluğu” içerisinde yürüyen bu tartıșmalar bir ortak fikir birliğine ulușmamıza katkı sağlayacaktır. Kantçı olmasak bile Kantçı bakıș açısını da dahil edeceğimiz bir uzlașı alanı üzerinde düșünmememize destek 
olacaktır. Örneğin, gördüğümüz gibi, kendisinin Kantçı bir yaklașımla hayvanları faydacılar gibi salt haz ve acı üzerinden ele almaması önemli ve anlamlıdır. Bizim akılsal hayvanlar olarak diğer hayvanlara hiçbir sonucu düșünmeden kendinde bir amaç olarak sokulabileceğimizi ve onlara yönelik kimi yükümlülüklerimiz olduğunu belirtir. Bu Kantçı iyi niyet kușkusuz değerlidir, sorun bu araçsal aklın hakimiyeti içerisinde Kantçı akılla düșünebilecek olgunluğu gösteremiyor olmamızdır. Kantçı anlamda akılsal benliğimizi inșa etme çabasından çok uzak olduğumuz bu postmodern konformist ve tüketim dönemlerinde, hayvanlara karșı bir amaç olarak yaklaşmak epey zor görünmektedir. Bugün için insanlar Kantçı bir haysiyet, onur ve șahsiyetle birbirlerine bile yaklașmaktan uzaktırlar. Özellikle aşırı taraflılıklar, bağlılıklar hukuksal değil araçsal aklı beslediği için Kantçı ahlakı tek başına yeterli görmek, insanın akılsallığına fazlasıyla umut bağlayan bir iyi niyetlilik olacaktır.

Üzerinde durmamız ve sorușturmayı yürütmemiz gereken temel nokta, insanların birbirlerine ve hayvanlara yaptıkları suiistimallerin, kötülüklerin nedenlerini ele almak ve bunları ortadan kaldıracak bir etiko-politik soruşturma yürütmektir. Bu noktada diğer ahlak kuramlarının Kantçılık eleștirisi üzerinden dikkat çektiği kimi konular gerçekten önemlidir. Örneğin Korsgaard'ın eleștirdiği ve muhtemelen eleștirebileceği de Waal, Singer, Nussbaum ve MacIntyre gibi isimler tutkulara, duygulara, bedene ve politik yașama daha fazla yönelirler. Örneğin de Waal ve MacIntyre'ın ahlakı birey temelinde değil toplumsal ilișkilerle ele almaları, üzerinde ciddiyetle durmamızı gerektirecek denli önemlidir. Çünkü toplumsal ilișkiler bağlamında diğer canlılara yöneldiğimiz takdirde hayvanlar ve insanlar arasındaki ortaklıklar Korsgaard'ın vurguladığından çok daha çarpıcı bir șekilde görünür olurlar. Ahlak ve diğer hayvanlara yükümlülükler insani bir yașam alanına sıkıștırılmaz. Ahlakın, de Waal'ın söylediği gibi, hayvanların yașamında ișler olduğu fark edilir. Bireyden hareket etmektense toplumdan hareket eden bir okumanın, insanların hayvanlarla ortaklıklarını göstermesi çok daha kolay olabilir. Bu sayede bizim toplumsal yașamımızda önemli bileșenler olan yașama mücadelesinin, üremenin, barınmanın, açlığın, dayanıșmanın, sevginin, merhametin, fedakarlığın ve ortak iyinin hayvanların yașamlarında ne denli merkezi olduğunu çok daha açık bir șekilde görebiliriz. Bizce Korsgaard'ın teorisinin en temel sorunu; 
amaçladı̆̆ı “Amaçlar Krallı̆̆ı”nı genişletme çabasında tek tek bireyin akılsallığından hareket etmesidir.

Son olarak șunu da belirtelim: Korsgaard teorik açıklamalarının pratik uzantısını yani pratik yașamlarımızda hayvanlara yönelik üzerinde durduğu yükümlülükleri çok tutarlı ve bașarılı bir șekilde ele alır. Söz ettiği yükümlülükleri yerine getirmek gerçekçi, ikna edici ve olasıdır. Özellikle küresel yașamın sorunları, dünyanın kaynaklarını tüketmedeki aşırılıkların yıkıcılıkları karșısında vejetaryen beslenmenin önemine ve sonuçlarına dikkat çekmesi anlamlıdır. Çünkü küresel ısınma, açlık sorunlarını düșündügüumüzde bu konuya duyarlılık göstermemiz sanki biraz zorunlu gibi görünüyor. Aksi durumda dünya hayvanlar kadar bizler için de yașayabileceğimiz bir ev olmaktan çıkabilir. Bu tehlikeli durum karș1sında, hayvanlara yönelik Korsgaardcı yükümlülükleri gerçekleștirmenin bizlerin yașamlarını daha iyi ve yașanılır kılacağı açıktır. Bugün için kimi temel sorunlarımız karșısında yapmamız gereken ve Korsgaard'ın da açık kılmaya çalıștığını düșündüğümüz basit gerçek şudur: Ne zaman ki hayvanları iyi yașatmayı öğrenir ve bașarırsak, onların iyi yașamasına izin verir ya da yardımcı olursak bizler de iyi yașamayı becerebiliriz.

\section{Kaynaklar}

Hughes, A. [yön.] (20I8). Alfa Kurt (Alpha). USA: Warner Bros..

Coetzee, J. M. (1999). The Lives of Animals. Princeton: Princeton University Press.

De Waal, F. (2006). Primates and Philosophers: How Morality Evolved. (Ed. S. Macedo \& J. Ober). Princeton: Princeton University Press.

Erkızan, H. N. (20I2). Aristoteles'ten Nussbaum'a İnsan. İstanbul: Sentez Yayınc1lık.

Kant, I. (2002). Ablâk Metafiziğinin Temellendirilmesi. (Çev. İ. Kuçuradi). Ankara: Türkiye Felsefe Kurumu Yayınları.

Korsgaard, C. M. (200o). Creating the Kingdom of Ends. Cambridge: Cambridge University Press.

Korsgaard, C. M. (2008). The Constitution of Agency: Essays on Practical Reason and Moral Psychology. Oxford: Oxford University Press.

Korsgaard, C. M. (2006). Morality and the Distinctiveness of Human Action. F. De Waal. Primates and Philosophers: How Morality Evolved. (Ed. S. Macedo \& J. Ober). Princeton: Princeton University Press, 98-II9. 
Korsgaard, C. M. (2009). Self-Constitution: Agency, Identity, and Integrity. Oxford: Oxford University Press.

Korsgaard, C. M. (20I2) (Online Pub. Date). Interacting with Animals: A Kantian Account. The Oxford Handbook of Animal Ethics. (Eds. T. L. Beacuhamp \& R. G. Frey). Oxford: Oxford University Press, 9I-II8.

Korsgaard, C. M. (2013). Kantian Ethics, Animals, and the Law. Oxford fournal of Legal Studies, 33 (4), 629-648.

Korsgaard C. M. (2018). Fellow Creatures: Our Obligations to the Other Animals. Oxford: Oxford University Press.

Harari, Y. N. (2015). Hayvanlardan Tanrılara Sapiens: İnsan Türünün Kısa Bir Taribi. (Çev. E. Genç). İstanbul: Yordam Kitap.

MacIntyre, A. (2002). Dependent Rational Animals: Why Human Beings Need the Virtues. Chicago: Open Court.

Mutlu, B. (2015). Martha Nussbaum'da İyi Yașam ve Talih. (Yayınlanmamıș DrT). İzmir: Ege Üniversitesi.

Nussbaum, M. C. (2007). Frontiers of fustice: Disability, Nationality, Species Membership. Cambridge, Massachusetts: The Belknap Press of Harvard University Press.

Nussbaum, M. C. (2012). (Online Pub. Date). The Capabilities Approach and Animal Entitlements. The Oxford Handbook of Animal Ethics. (Eds. T. L. Beacuhamp \& R. G. Frey). Oxford: Oxford University Press, 228-250.

Nussbaum, M. C. (2013). Political Emotions: Why Love Matters for Fustice. Cambridge, Massachusetts: Belknap Press of Harvard University Press.

Regan, T. (2004). The Case for Animal Rights. California: University of California Press.

Regan, T. (2007). Kafesler Boșalsın: Hayvan Haklarıyla Yüzleșmek. (Çev. S. Çağlayan). İstanbul: İletișim Yayınları.

Singer, P. (2005). Hayvan Özgürleșmesi. (Çev. H. Doğan). İstanbul: Ayrıntı Yayınlar1.

Sorabji, R. (1993). Animal Minds and Human Morals: The Origins of the Western Debate. Ithaca, NY: Cornell University Press. 
Öz: C. M. Korsgaard Kantçı bir filozoftur, eserlerinde Kant'nn rehberliği altında hareket eder ve onun rehberliğinde "fail ve özdeșlik" (identity), "benlik/kendilik" (self), "normatiflik”, "pratik akıl", "hayvanlar" gibi önemli tartıșmalar yürütür. Eserlerinde özellikle nornatifliğin insan doğasıyla zorunlu ilișkisi olduğunu, bir zorunluluk biçimi olarak insan doğasında psikolojik bir güce sahip olduğunu, insan ruhunun olușturucusu durumunda olduğunu ileri sürer. Korsgaard șuna inanır: Sadece rasyonel insan "inandığı ve yaptığı șeyleri yönetecek normatif ilkelere, yasalara" ulașır, "normatif olarak kendini-yönetme” becerisi gösterir. Bu beceri diğer insan olmayan hayvanlarda mevcut değildir; hepsi akıl (reason) kapasitesine, rasyonaliteye sahip olmayıp salt evrimsel içgüdüleri, doğal yapıları ile hareket ederler. Gelgelelim Korsgaard bu farklılığı abartmamamız gerektiğini, bu farklılığın bizleri ahlaki olarak onlardan daha üstün kılmadığını söyler. Çünkü hayvanlar da bizler gibi yaşamlarına değerler yüklemekte, belli iyiler ve amaçlar peșinde koșmakta belli ișlevlerle (ergon) yașamaktadırlar. Bu çalışmamızda Korsgaard'ın hayvanlara yönelik ortaya koyduğu Kantçı teoriyi göreceğiz.

Anahtar Kelimeler: Korsgaard, ahlak, rasyonalite, hayvanlar, yükümlülük. 


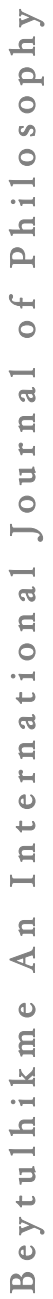

